\title{
Supporting Information for: \\ Multiphase chemistry controls inorganic chlorinated and nitrogenated compounds in indoor air during bleach cleaning
}

James M. Mattila ${ }^{1}$, Pascale S. J. Lakey², Manabu Shiraiwa², Chen Wang ${ }^{3}$, Jonathan P.D. Abbatt ${ }^{3}$, Caleb Arata $^{4,5}$, Allen H. Goldstein ${ }^{5,6}$, Laura Ampollini ${ }^{7}$, Erin F. Katz ${ }^{8}$, Peter F. DeCarlo7,8, Shan Zhou', Tara F. Kahan $^{9,10}$, Felipe J. Cardoso-Saldaña ${ }^{11}$, Lea Hildebrandt Ruiz ${ }^{11}$, Andrew Abeleira ${ }^{1}$, Erin K. Boedicker ${ }^{1}$, Marina E. Vance ${ }^{12}$, Delphine K. Farmer ${ }^{1 *}$

${ }^{1}$ Department of Chemistry, Colorado State University, Fort Collins, Colorado 80523, United States

${ }^{2}$ Department of Chemistry, University of California, Irvine, California 92697, United States

${ }^{3}$ Department of Chemistry, University of Toronto, Toronto, ON Canada M5S 3H6

${ }^{4}$ Department of Chemistry, University of California, Berkeley, California 94720, United States

${ }^{5}$ Department of Environmental Science, Policy, and Management, University of California, Berkeley, California 94720, United States

${ }^{6}$ Department of Civil and Environmental Engineering, University of California, Berkeley, California 94720, United States

${ }^{7}$ Department of Civil, Architectural, and Environmental Engineering, Drexel University, Philadelphia, Pennsylvania 19104, United States

${ }^{8}$ Department of Chemistry, Drexel University, Philadelphia, Pennsylvania 19104, United States

${ }^{9}$ Department of Chemistry, Syracuse University, Syracuse, New York 13244, United States

${ }^{10}$ Department of Chemistry, University of Saskatchewan, Saskatoon, SK Canada S7N 5C9

${ }^{11}$ Center for Energy and Environmental Resources, The University of Texas at Austin, Austin, Texas 78758, United States

${ }^{12}$ Department of Mechanical Engineering, University of Colorado Boulder, Boulder, Colorado 80309, United States

*Correspondence to: Delphine K. Farmer (Delphine.Farmer@colostate.edu)

No. of pages: 36

No. of figures: 15

No. of tables: 7 


\section{Supporting Information Text}

Section S1: Detailed kinetic model description including assumptions and simplifications. The building interior has a volume of $250 \mathrm{~m}^{3}$ and the bleached surface area was $40 \mathrm{~m}^{2}$. In the model, we assume that the bleach thickness was $0.01 \mathrm{~cm}$. We did not treat changes in the bleach thickness over time as the thickness was unmeasured and the rate of evaporation was unknown. Bleach contains $\sim 6 \% \mathrm{NaOCl}$ by mass. The bleach had been diluted by a factor of 32 before being applied to the floor. The model considers an initial concentration of aqueous $\mathrm{OCl}^{-}$of $1.5 \times 10^{19}$ molecules $\mathrm{cm}^{-3}$. The $\mathrm{pH}$ of the bleach was varied in the model until the gas-phase $\mathrm{HOCl}$ and $\mathrm{Cl}_{2} \mathrm{O}$ data were well fit. This approach resulted in a $\mathrm{pH}$ range of $9.2-9.6$. These values are reasonable considering the bleach $\mathrm{pH}$ of $\sim 12.6$ and a dilution factor of 32 with possible further acidification by other molecules present on the floor. The $\mathrm{pH}$ was assumed to remain constant over time as changes were unmeasured. During the experiments, the bleach was applied throughout a period of 10 minutes. However, in the model, applying the bleach over this extended time period was challenging, and the best model-measurement agreement was obtained when the reactions were switched on $\sim 2.5$ minutes after bleach cleaning had started. After a set time ( $0.31-0.56$ hours; determined by observations in measurement data), we assumed that the bleach had fully evaporated away and sorption and desorption from the bleach mixture in the model was switched off. Anything remaining in the bleach was then assumed to act as a residue on the floor.

Mass-transport across the boundary layer provides kinetic limitations for uptake into the bleach and was assumed to be influenced by eddy diffusion such that the gas-phase diffusion coefficient $\left(D_{\mathrm{h}, \mathrm{z}}\right)$ at a height, $h$, above a surface could be calculated as:

$$
D_{h, Z}=D_{g, Z}+K_{e} \times h^{2}
$$

where $D_{\mathrm{g}, \mathrm{z}}$ is the gas-phase diffusion coefficient under non-turbulent conditions and $K_{\mathrm{e}}$ is the turbulence intensity. The values of $D_{\mathrm{g}, \mathrm{z}}$ are listed in Table S3 while the values of $K_{\mathrm{e}}$ are listed in Table S4. Air exchange rates are also listed in Table S4 and were constrained by measurements described in Section S2.

We include photolysis rates (j) derived from solar irradiance measurements performed indoors during HOMEChem (section S2; Figure S7). These solar irradiance measurements were performed directly adjacent to windows in the house; resultant photolysis rates likely do not account for the spatial variability due to the inhomogeneous transmission of outdoor light to indoors. We therefore treat these measured photolysis rates as upper-limits, and accordingly tune these values in our model to match measurement observations. Sensitivity tests revealed that the photolysis rate of $\mathrm{ClNO}_{2}, \mathrm{NO}_{3}$ and $\mathrm{HONO}$ 
were insensitive up to the maximum photolysis rate while the photolysis rate of $\mathrm{Cl}_{2}$ and $\mathrm{HOCl}$ had to be at least a factor of 10 and 5 lower than the maximum value, respectively, in order to reproduce respective measurement data. The model results were still slightly sensitive to the $\mathrm{NO}_{2}$ photolysis rate when the maximum value was decreased by a factor of 50 . Modeled $\mathrm{O}_{3}$ mixing ratios were very sensitive to indoor photolysis processes (e.g. reactions 8, 33, 35, and 41 in Table S2). The slight enhancements in measured indoor $\mathrm{O}_{3}$ (measurement details in Farmer et al. ${ }^{1}$ ) are reproducible across bleach cleaning experiments, even during the evening in the absence of transmission of outdoor sunlight (20:35 on 10 June 2018; Figure S8). We therefore suspect these enhancements were not driven by photochemistry. $\mathrm{NO}$ reacts with $\mathrm{ClO}$ to produce $\mathrm{NO}_{2}$ and $\mathrm{Cl}$., 3 However, we observe consistent decays in $\mathrm{NO}$ mixing ratios across bleach cleaning experiments, even in the absence of transmission of outdoor sunlight (20:35 on 10 June 2018; Figure S3 and S8). We therefore do not consider NO loss to be driven by photochemistry (i.e. loss via $\mathrm{ClO}$ is unlikely). We determined that measurement observations herein are best reproduced by decreasing upper-limit photolysis rates by a factor of 50 . Photolysis rates used in the model are reported in Table S4.

Other unknown or uncertain parameters including some rate coefficients, losses to surfaces and uptake coefficients (see Table S4) were varied systematically and iteratively until the measurements could be reproduced. A surface mass accommodation of 1 and a desorption lifetime of 1 ns was assumed for all (semi)volatile species.

\section{Section S2: Additional HOMEChem measurement details.}

Air exchange rate.

We determine the air exchange rate (AER) of the test house via the monitoring of a continuously emitted inert tracer gas (butane-d3, Cambridge Isotope Laboratories) with a PTR-TOF-MS. This method is detailed in Liu et al. ${ }^{4}$ AER values calculated during bleach cleaning experiments are in Table S4.

\section{PTR-TOF-MS sensitivity estimation.}

We estimate PTR-TOF-MS sensitivity toward $\mathrm{NH}_{2} \mathrm{Cl}$ and $\mathrm{NHCl}_{2}$ following $\mathrm{Zhao}$ and $\mathrm{Zhang} 5$, and assuming a proton-transfer reaction rate of a typical VOC $\left(\mathrm{k}=2.5 \times 10^{-9} \mathrm{~cm}^{3} \mathrm{~s}^{-1}\right)$. Typically, PTR-TOF-MS sensitivity errors for uncalibrated VOCs are around $\pm 50 \%$. Given our limited information in constraining PTR-TOFMS sensitivity toward $\mathrm{NH}_{2} \mathrm{Cl}$ and $\mathrm{NHCl}_{2}$, these errors could be larger. PTR-TOF-MS sensitivities can depend on humidity, and calibrations were conducted at $0 \% \mathrm{RH}$. Fluctuations in sensitivity due to indoor 
$\mathrm{RH}$ should be negligible during this study given the low variability in the humidity of indoor air during the experiments (typically $\pm 2 \% \mathrm{RH}$ ).

Particulate matter surface area.

We determine particulate matter (PM) surface area with an Ultra High Sensitivity Aerosol Spectrometer (UHSAS; Droplet Measurement Technologies, Inc.) (Figure S1). The UHSAS sampled PM between 60 $1000 \mathrm{~nm}$ through a copper sampling line ( $8 \mathrm{~m}$ length; $0.635 \mathrm{~cm}$ ID; $0.9525 \mathrm{~cm} \mathrm{OD)}$ ), attached to a valveswitching system which included a HEPA bypass and a Nafion dryer. Additional details of these measurements at HOMEChem are found in Farmer et al. ${ }^{1}$ We acknowledge that this submicron aerosol surface area is an underestimate of the total PM surface area during cooking events.

\section{Indoor photolysis rates.}

Wavelength-resolved spectra of sunlight entering the house were measured using an Ocean Optics USB4000 spectrometer attached with a $1 \mathrm{~m}$ fiber optic cable (Thorlabs) and a Spectralon cosine receptor. Photon fluxes $(F)$ were estimated as being equal to the measured irradiance. This estimation is likely accurate under sunny conditions at low solar zenith angles (i.e. when sunlight entering the house is largely collimated and unidirectional), as discussed in Kowal et al. ${ }^{6}$ Irradiance likely underestimates photon flux when sunlight is highly diffuse, such as on cloudy days. The average photon fluxes reported near the windows (shown in Figure 4 in the manuscript) are therefore likely underestimated by up to $25 \%$. Photolysis rate constants $(J)$ of $\mathrm{HOCl}, \mathrm{Cl}_{2}, \mathrm{ClNO}_{2}, \mathrm{NO}_{2}, \mathrm{NO}_{3}$, and $\mathrm{HONO}$ were calculated (Figure S7; Table S2) as described previously using the measured photon fluxes $(F)$ and reported absorption cross sections $(\sigma)$ and photolysis quantum yields $(\phi):^{6}$

$$
J=\int_{\lambda_{i}}^{\lambda_{j}} \sigma(\lambda) \phi(\lambda) F(\lambda) d \lambda
$$

Continuous measurements were made directly adjacent to windows at 1-minute resolution. As a result, these rate constants represent local values. Indoor solar photon flux has been shown to decrease linearly with distance from windows and displayed high spatial heterogeneity. ${ }^{1,6}$ We therefore treat these local photolysis rates as upper bounds. We note that the main function of these measurements was to characterize the indoor diel profile, rather than the absolute magnitudes, of photolysis rates, in that the magnitudes of these rates were tuned in our kinetic model to match indoor observations (see section S1). Additional details of these measurements during HOMEChem are found in Farmer et al. ${ }^{1}$ 
Kowal et al. ${ }^{6}$ demonstrated that UV photon fluxes from indoor lighting fixtures decay very rapidly with distance. We therefore expect negligible photolysis due to indoor lighting during HOMEChem.

Additional AMS measurement details.

Cooking organic aerosol is largely comprised of molecules with lower oxidation states (e.g. oleic acid and other unsaturated fatty acids). ${ }^{34} \mathrm{Xu}$ et al..$^{35}$ reported an AMS relative ionization efficiency (RIE) of 2-7 for cooking organic aerosol. Organic PM mass concentration data reported in Figure S5 use RIE = 1.4, a value typical for ambient organic aerosols. ${ }^{35}$ As a result, these organic PM mass concentrations during cooking events (e.g. Figure S5a-d) are likely overestimated. We use an RIE of 1.3 for AMS measurements of non-refractory particulate $\mathrm{Cl}^{-}$during all experiments herein.

We provide additional I- TOF-CIMS measurement details in the subsequent sections.

Section S3: I- TOF-CIMS operation and data processing. Ultra-high purity (UHP) $\mathrm{N}_{2}$ (Airgas) flowed ( 0.7 $\left.\mathrm{L} \mathrm{min}{ }^{-1}\right)$ through a heated oven $\left(50^{\circ} \mathrm{C}\right)$ containing methyl iodide $\left(\mathrm{CH}_{3} \mathrm{l}\right)$ permeation tubes $(\mathrm{VICl}$, Dynacalibrator). The resulting $\mathrm{CH}_{3} \mathrm{l}$-saturated $\mathrm{N}_{2}$ stream passed through a ${ }^{210}$ Po ionizer to generate $\mathrm{I}^{-}$ reagent ions, which then entered the ion-molecule reactor (IMR) region of the instrument. Here, analytes sampled from ambient air (M) form charged iodide-analyte adducts ([I+M $\left.]^{-}\right)$via clustering reactions with $\mathrm{I}^{-}$, or ligand switching reactions with $\mathrm{IH}_{2} \mathrm{O}^{-; 7,8}$ followed by transmission via ion optics to the TOF region of the instrument for detection. We controlled mass spectral data acquisition with TofDaq Recorder (Tofwerk AG; extraction frequency $=26 \mathrm{kHz} ; \mathrm{m} / \mathrm{z}$ range $=1.63-456.80$ ).

We processed I- TOF-CIMS data in Igor Pro (WaveMetrics Inc., version 6) with Tofware (Tofwerk AG, Aerodyne Research Inc., version 2.5.10), which calculated mass spectral baseline, fitted peak shape, and mass resolution. Tofware uses the integrated area of fitted peak functions to mass spectral data to calculate signal time series of mass spectral peaks. The peak fitting algorithm featured in Tofware automatically calculates relative isotopic contributions of fitted peak functions based on the elemental assignment of a mass spectral peak. From this, we are able to confirm the elemental compositions of peaks in our TOF-CIMS spectra, including the chlorinated and nitrogenated compounds discussed herein. Mass calibration took place post-acquisition using a three-parameter fit to the $\mathrm{NO}_{2}^{-}, \mathrm{I}^{-}, \mathrm{IH}_{2} \mathrm{O}^{-}, \mathrm{ICH}_{2} \mathrm{O}_{2}^{-}$, $\mathrm{IC}_{3} \mathrm{H}_{6} \mathrm{O}_{3}{ }^{-}$, and $\mathrm{I}_{3}{ }^{-}$peaks. These peaks had consistently high resolution and contained no interferences nor 
overlapping peaks throughout the campaign. TOF-CIMS mass accuracy was $4 \mathrm{ppm}$ (campaign average of mass calibrant ions), and resolution $(\mathrm{m} / \Delta \mathrm{m})$ was $>4000$. Tofware's high-resolution peak fitting algorithm extracted time series of mass spectral signal $(\mathrm{Hz})$ for detected analytes. We performed additional data analysis, including background subtraction, normalization, and mixing ratio calculation/estimation in Igor Pro. We normalized measured analyte data to the total reagent ion signal following Bertram et al. ${ }^{9}$, by multiplying mass spectral signal by the ratio of the average total reagent ion signal during an hourly background measurement to the total reagent ion signal during periods of analyte measurement. Here, we calculated total reagent ion signal as the sum of $\mathrm{I}^{-}$and $\mathrm{IH}_{2} \mathrm{O}^{-}$signal. This normalization method ensured that any changes in analyte signal were not due to variations in total reagent ion signal. We calculated I- TOF-CIMS instrumental detection limits for various bleach-related compounds measured at HOMEChem following Bertram et al. ${ }^{9}$, and provide them in Table S5.

\section{Section S4: Shared TOF-CIMS sampling inlet setup and on-site alkanoic acid calibrations at}

HOMEChem. Our I- TOF-CIMS, and an acetate ( $\mathrm{Ac}^{-}$) TOF-CIMS shared a sampling inlet and calibration system, outlined in Figure S9. We deployed both TOF-CIMS instruments in a temperature-controlled trailer directly adjacent to the UTest house. We sampled ambient air from inside the house through perfluoroalkoxy alkane (PFA) tubing $(0.3175 \mathrm{~cm}$ ID) extending from the kitchen area of the UTest house to inside the trailer at $\sim 4 \mathrm{~L} \mathrm{~min}^{-1}$. We also sampled outdoor air through PFA tubing $(0.3175 \mathrm{~cm} \mathrm{ID)}$, extending from roughly $1 \mathrm{~m}$ above the trailer to inside the trailer at $\sim 4 \mathrm{~L} \mathrm{~min}^{-1}$. These indoor and outdoor sampling lines met at the three-way solenoid isolation valve (NResearch Inc.). Total indoor and outdoor sampling inlet lengths were $7 \mathrm{~m}$ and $5 \mathrm{~m}$, respectively, for the I- TOF-CIMS; and $10 \mathrm{~m}$ and $8 \mathrm{~m}$, respectively, for the Ac- TOF-CIMS.

Ambient sampling typically followed an automated hourly indoor/outdoor switching cycle (Figure S10). At the start of each hour, we performed two-minute instrumental background measurements by introducing an overflow of ultra-zero grade air (UZA, Airgas) to both TOF-CIMS using a mass-flow controller (MFC). Indoor/outdoor ambient sampling comprised the remainder of the hourly cycle. We neglect data collected within 60 seconds of a valve-switching event to avoid the influence of potential sampling line effects. Sampled air entered the IMR of both TOF-CIMS at $\sim 2 \mathrm{~L} \mathrm{~min}^{-1}$. We performed inline measurements of ambient temperature and relative humidity (RH) using a digital sensor (Sensirion SHT21) controlled by an EyeOn control system (Aerodyne Research Inc.). We 
automated valves, MFCs, and mass spectral data acquisition using homebuilt programs (LabVIEW, National Instruments).

We generated gas-phase calibration standards of formic $\left(\mathrm{CH}_{2} \mathrm{O}_{2}\right)$, acetic $\left(\mathrm{C}_{2} \mathrm{H}_{4} \mathrm{O}_{2}\right)$, propionic $\left(\mathrm{C}_{3} \mathrm{H}_{6} \mathrm{O}_{2}\right)$, butyric $\left(\mathrm{C}_{4} \mathrm{H}_{8} \mathrm{O}_{2}\right)$, and valeric acid $\left(\mathrm{C}_{5} \mathrm{H}_{10} \mathrm{O}_{2}\right)$ by flowing ultra-high purity (UHP) $\mathrm{N}_{2}$ (Airgas) through a heated oven $\left(40^{\circ} \mathrm{C}\right)$ containing permeation tubes ( $\mathrm{VICl}$, Dynacal) of each compound. We determined temperature-dependent mass losses gravimetrically, enabling us to calculate measured mixing ratios of each standard. We performed single-point hourly standard addition calibrations on $12-$ $16,18,25$, and 27 June by introducing gas-phase calibrant into the ambient sampling stream and measuring the signal change due to a known stepwise change in mixing ratio (Figure S9). Standard additions took place at nights between the hours of 21:00 and 05:00, i.e. in the absence of interferences from indoor experiments. Using a sufficiently small calibrant flow during standard additions ( $0.1 \mathrm{~L} \mathrm{~min}^{-}$ 1; $2.5 \%$ of total sample flow) ensured that any analyte dilution from this flow was negligible. We also performed five-point external standard calibrations of these compounds on 9, 14, 23, and 28 June by diluting gas-phase calibrant in UZA (Airgas) using an MFC (MKS Instruments) (Figure S9). All tubing used downstream of our calibration source was $0.3175 \mathrm{~cm}$ ID PFA.

Section S5: I- TOF-CIMS calibrations for $\mathrm{Cl}_{2}, \mathrm{HOCl}, \mathrm{N}_{2} \mathrm{O}_{5}$, and $\mathrm{CINO}_{2}$. We performed in-laboratory I- TOFCIMS calibrations for $\mathrm{Cl}_{2}, \mathrm{HOCl}, \mathrm{N}_{2} \mathrm{O}_{5}$, and $\mathrm{CINO}_{2}$ shortly after the conclusion of the HOMEChem campaign. We detect all calibrant compounds as iodide-analyte adducts. We minimize lengths of Teflon tubing (PFA; $0.3175 \mathrm{~cm}$ ID) used in all calibration setups to mitigate any inlet-effects.

$\mathrm{Cl}_{2}$ and $\mathrm{HOCl}$ calibrations.

We conducted five-point external standard calibrations for $\mathrm{Cl}_{2}$ using a gas-phase standard (Airgas; 2 ppm $\mathrm{Cl}_{2}$ in UHP $\mathrm{N}_{2} ; 99.5 \%$ purity). We calibrated the instrument for $\mathrm{HOCl}$ based on the methodology of Foster et al. ${ }^{10}$ and Lawler et al. ${ }^{11}$. Here, we flowed UHP $\mathrm{N}_{2}$ (Airgas; $100 \mathrm{sccm}$ ) over the headspace of a $0.3 \mathrm{M}$ $\mathrm{NaOCl}$ solution (RICCA; commercial grade), generating a steady flow of a gaseous mixture containing $\mathrm{HOCl}$ and $\mathrm{Cl}_{2}$. This initial headspace flow entered the instrument inlet to measure $\mathrm{HOCl}$ and $\mathrm{Cl}_{2} \mathrm{I}^{-} \mathrm{TOF}-$ CIMS response. We then redirected the headspace flow into a glass tube $(2.5 \mathrm{~cm} \mathrm{OD})$ containing an aqueous slurry of $\mathrm{NaCl}$ (EMD Millipore; GR ACS) and $\mathrm{HCl}$ (EMD Millipore; GR ACS), converting $\mathrm{HOCl}$ to $\mathrm{Cl}_{2} \cdot{ }^{10}$ We held the glass tube containing this slurry in an ice bath to inhibit volatilization of $\mathrm{HCl}$. We 
determined I- TOF-CIMS sensitivity to $\mathrm{HOCl}$ from the measured increase in $\mathrm{Cl}_{2}$ signal, and associated decrease in $\mathrm{HOCl}$ signal following this conversion. We calculated $\mathrm{Cl}_{2}$ and $\mathrm{HOCl}$ - TOF-CIMS sensitivities of 4. \pm 1 . $\mathrm{Hz} \mathrm{pptv}^{-1}$ and $0.4 \pm 0.2 \mathrm{~Hz} \mathrm{pptv}^{-1}$, respectively.

$\mathrm{N}_{2} \mathrm{O}_{5}$ calibration.

We flowed $\sim 10 \mathrm{sccm}$ UZA (Airgas) through a Hg lamp (UVP) to generate ozone $\left(\mathrm{O}_{3}\right)$, which reacted with $\sim 15 \mathrm{sccm}$ nitrogen dioxide $\left(\mathrm{NO}_{2}\right.$; Praxair, Inc.) gas to produce $\mathrm{NO}_{3}$, which further reacted with $\mathrm{NO}_{2}$ to generate a flow of gaseous $\mathrm{N}_{2} \mathrm{O}_{5}$. We determined mixing ratios of $\mathrm{N}_{2} \mathrm{O}_{5}$ produced via this process using a custom-built cavity ring-down spectroscopy (CRDS) instrument. ${ }^{12-14}$ We directed the $\mathrm{N}_{2} \mathrm{O}_{5}$ standard to the I- TOF-CIMS sampling inlet to determine instrumental sensitivity to $\mathrm{IN}_{2} \mathrm{O}_{5}$ ' and 'total $\mathrm{N}_{2} \mathrm{O}_{5}$ ' (taken as $\left.\mathrm{IN}_{2} \mathrm{O}_{5}{ }^{-}+\mathrm{NO}_{3}{ }^{-}\right)^{8}$ via five-point external standard calibrations. We calculated a total $\mathrm{N}_{2} \mathrm{O}_{5} \mathrm{I}^{-}$TOF-CIMS sensitivity of 50. $\pm 10 . \mathrm{Hz} \mathrm{pptv}^{-1}$.

$\mathrm{ClNO}_{2}$ calibration.

We determined instrumental response to $\mathrm{CINO}_{2}$ via five-point external standard calibrations. Here, we flowed $\sim 25 \mathrm{sccm}$ gaseous $\mathrm{N}_{2} \mathrm{O}_{5}$ into a glass tube $(2.5 \mathrm{~cm}$ OD) containing an aqueous $\mathrm{NaCl}$ (EMD Millipore; GR ACS) slurry, thereby converting $\mathrm{N}_{2} \mathrm{O}_{5}$ to $\mathrm{ClNO}_{2} \cdot{ }^{15}, 16$ We determined $<10 \% \mathrm{~N}_{2} \mathrm{O}_{5}$ formed $\mathrm{HNO}_{3}$ as a side-product, based on our I- TOF-CIMS sensitivity to $\mathrm{HNO}_{3}$ determined via external standard calibration utilizing an $\mathrm{HNO}_{3}$ permeation tube standard (KIN-TEK Analytical, Inc.). We calculated a $\mathrm{CINO}_{2}$ I- TOF-CIMS sensitivity of $6 . \pm 3$. $\mathrm{Hz} \mathrm{pptv}^{-1}$.

Accounting for dependence of I- TOF-CIMS sensitivities on ambient humidity.

Water vapor present in the IMR region of the TOF-CIMS affects I- TOF-CIMS sensitivities for several compounds. Ambient humidity was therefore as a potential matrix effect during our HOMEChem measurements. We accounted for this by performing our post-campaign calibrations (and associated instrumental background measurements) of $\mathrm{Cl}_{2}, \mathrm{HOCl}, \mathrm{N}_{2} \mathrm{O}_{5}$, and $\mathrm{ClNO}_{2}$ with a dilution flow of humidified ultra zero grade air (UZA; Airgas). We flowed UZA through a glass bubbler containing LC-MS grade $\mathrm{H}_{2} \mathrm{O}$ (EMD Millipore), generating a UZA flow saturated with $\mathrm{H}_{2} \mathrm{O}$. We controlled the final relative 
humidity $(\mathrm{RH})$ of this flow by mixing a second flow of UZA downstream of the bubbler, and measured its final RH using an in-line RH sensor (OMEGA Engineering, Inc; HX71-V1). Mass-flow controllers (MFCs; MKS) modulated UZA flow rates. We maintained a setpoint RH during calibrations with a proportionalintegral-derivative (PID) loop using homebuilt software (LabVIEW; National Instruments) interfaced with the MFCs and RH sensor. The UZA dilution flows used for these calibrations/backgrounds were humidified such that the partial pressure of water vapor in the IMR $\left(P_{\mathrm{H} 20, I M R}\right)$ was comparable to that during ambient sampling at HOMEChem $\left(\mathrm{P}_{\mathrm{H} 2 \mathrm{O}, \mathrm{MMR}} \approx 1.4 \mathrm{mbar}\right.$, corresponding to $\sim 55 \% \mathrm{RH}$ measured inline during HOMEChem).

Figure S11 shows how in-laboratory external standard calibrations of $\mathrm{C}_{1}-\mathrm{C}_{5}$ alkanoic acids using a dilution flow of humidified UZA effectively reproduce the $\mathrm{RH}$ matrix effects observed during standard addition calibrations performed at HOMEChem (described in section S4), further displaying the efficacy of this approach. Trends in I- TOF-CIMS $\mathrm{C}_{1}-\mathrm{C}_{3}$ alkanoic acid sensitivities as a function of RH are consistent with previous work. ${ }^{17}$

We assess the RH-dependent sensitivity of $\mathrm{N}_{2} \mathrm{O}_{5}$ and $\mathrm{ClNO}_{2}$ further by performing external standard calibrations under various humidity conditions. We observe a similar trend in humiditydependent $\mathrm{N}_{2} \mathrm{O}_{5}$ I- TOF-CIMS sensitivity to that observed by Kercher et al. ${ }^{18}$ As humidity in the IMR increases, $\mathrm{IN}_{2} \mathrm{O}_{5}{ }^{-}$sensitivity increases and $\mathrm{NO}_{3}{ }^{-}$sensitivity decreases, while the total $\mathrm{N}_{2} \mathrm{O}_{5}$ sensitivity remains fairly constant (albeit decreases slightly with increasing humidity); indicating that the massdependent transmission efficiency of these compounds through the instrument is also fairly constant (Figure $\mathrm{S} 12$ ). $\mathrm{ClNO}_{2}$ sensitivity does not vary significantly under the HOMEChem conditions as $\mathrm{P}_{\mathrm{H} 20, \mathrm{IMR}}>$ 0.6 mbar ( 30\% RH measured in-line during HOMEChem) (Figure S13). This trend in RH-dependent ITOF-CIMS $\mathrm{CINO}_{2}$ sensitivity agrees with that observed by Kercher et al. ${ }^{18}$

We did not further assess RH-dependent I- TOF-CIMS sensitivity for $\mathrm{Cl}_{2}$ because the $\mathrm{RH}$ dependent $\mathrm{Cl}_{2}$ sensitivities reported by Lee et al. ${ }^{17}$ were relatively invariable as $\mathrm{P}_{\mathrm{H} 20, \mathrm{IMR}}>0.4 \mathrm{mbar}$. We anticipate a similar result as trends in $\mathrm{RH}$-dependent I- TOF-CIMS sensitivity are fairly consistent across instruments (irrespective of the absolute magnitude of these trends). We do not further characterize the RH-dependent I- TOF-CIMS sensitivity of $\mathrm{HOCl}$. Some variability in calculated $\mathrm{HOCl}$ mixing ratios may thus be caused by variations in ambient RH during HOMEChem. However, indoor RH typically varied $\pm 2 \%$ during the experiments, and we expect a subsequently negligible fluctuation in I- TOF-CIMS sensitivity to $\mathrm{HOCl}$. 
Our instrumental background measurements at HOMEChem were performed with dry $(\mathrm{RH}=0 \%)$ UZA, and therefore may not be a true representation of analyte background signals measured in sampled indoor air $\left(\mathrm{RH} \approx 55 \%\right.$, corresponding to $\mathrm{P}_{\mathrm{H} 20, \mathrm{IMR}} \approx 1.4 \mathrm{mbar}$ in Austin, $\mathrm{TX}$ ). To address this, we performed post-campaign measurements of I- TOF-CIMS background signals for $\mathrm{HOCl}, \mathrm{Cl}_{2}, \mathrm{Cl}_{2} \mathrm{O}, \mathrm{ClNO}_{2}$, $\mathrm{NHCl}_{2}$, and $\mathrm{NCl}_{3}$ (detected as [I+M] ${ }^{-}$adducts) while sampling UZA of variable $\mathrm{RH}$. The $\mathrm{RH}$ of $\mathrm{UZA}\left(\mathrm{RH}_{\mathrm{UZA}}\right)$ during these experiments ranged from $0-70 \%$ (corresponding to $\mathrm{P}_{\mathrm{H} 20, \mathrm{IMR}}=0-1.4$ mbar in Fort Collins, $\mathrm{CO})$. Instrumental background signals for all compounds tested were higher by a factor of $3-8$ when $\mathrm{RH}_{\mathrm{UZA}}=70 \%$ compared to $\mathrm{RH}_{\mathrm{UZA}}=0 \%$. However, measured background signals for these compounds at HOMEChem were typically on the order of $10^{0}-10^{1} \mathrm{~Hz}$, while respective measured signals reached orders of $10^{4}-10^{5} \mathrm{~Hz}$ during bleach cleaning. We therefore conclude that the lack of humidity in the $\mathrm{I}^{-}$ TOF-CIMS background measurements of these compounds performed during HOMEChem does not significantly impact their respective background-subtracted I- TOF-CIMS signals (and subsequently mixing ratios) measured during bleach cleaning.

Section S6: Voltage scanning for I- TOF-CIMS sensitivity estimation. Transmission of iodide-analyte adducts though the TOF-CIMS is controllable by systematically increasing (or 'scanning') the voltage gradient (dV), and therefore electric field strength, between any adjacent pair of ion optics components in the ion transmission region of the instrument. ${ }^{8,} 19$ Increasing electric field strength leads to enhanced collisionally-induced dissociation of these adducts, and a decrease in their overall transmission. Cluster transmission decreases in a sigmoidal fashion with increasing $d V .{ }^{8,19}$ An important empirical parameter related to I- TOF-CIMS sensitivity, $\mathrm{dV}_{50}$, is calculated as the half-maximum of a sigmoidal fit to these data. ${ }^{8,19} \mathrm{dV}_{50}$ is a proxy for I- adduct binding enthalpy; ${ }^{8}$ the strength of these adducts dictate their transmission through the instrument, thereby directly influencing TOF-CIMS sensitivity to these adducts. ${ }^{8,20}$

In this study, we scanned the 'SSQ back - lens skimmer' component relation. Details of this component relation, and how we perform these voltage scanning experiments are found in Brophy and Farmer ${ }^{19}$. We plot the logarithm of I- TOF-CIMS sensitivities for a variety of calibrant compounds $\left(\mathrm{C}_{1}-\mathrm{C}_{5}\right.$ alkanoic acids, $\mathrm{HNO}_{3}, \mathrm{~N}_{2} \mathrm{O}_{5}$ ) against their respective $\mathrm{dV}_{50}$ values (Figure S14). We determined calibrant sensitivities via in-laboratory external standard calibrations performed shortly after HOMEChem (detailed in section S5). We also performed voltage scanning experiments during these calibration periods to determine calibrant $d V_{50}$ values. We performed these experiments under variable $P_{H 20, I M R}$ 
settings (see section S5) to assess how ambient humidity affects the $\mathrm{dV}_{50}$-sensitivity relationship (Figure S14). Here, we observe a linear $\left(r^{2}=0.92-0.98\right)$ relationship between $\log \left(\right.$ sensitivity) and $d V_{50}$, with linearity typically increasing as humidity increases. Further, the spread between linear fits in $\log$ (sensitivity) space decreases above 0.6 mbar, suggesting that variability in estimated sensitivity attributable to $\mathrm{P}_{\mathrm{H} 2 \mathrm{O}, \mathrm{IMR}}$ decreases with increasing water vapor present. Additionally, we performed voltage scanning during various periods throughout $\mathrm{HOMEChem}$ to determine $\mathrm{dV}_{50}$ values of gas-phase compounds present in ambient air (i.e during bleach cleaning).

We used this relationship as a model for sensitivity (and therefore mixing ratio) estimation by inputting $d V_{50}$ values of compounds detected in ambient air during HOMEChem into the linear regressions used in Figure S14. We choose the $\mathrm{dV}_{50}$-sensitivity relationship at $\mathrm{P}_{\mathrm{H} 20, \mathrm{IMR}}=1.5 \mathrm{mbar}$ to estimate $\mathrm{Cl}_{2} \mathrm{O}, \mathrm{NHCl}_{2}$, and $\mathrm{NCl}_{3}$ sensitivities during $\mathrm{HOMEChem}$, as these humidity settings most closely match those observed during bleach cleaning activities. We considered $\mathrm{N}_{2} \mathrm{O}_{5}$ a 'maximally' sensitive compound, in that it forms strongly bound adducts with $\mathrm{I}^{-}$at the collision limit (see section S5).8, 21 Therefore, any compound with a $\mathrm{dV}_{50} \geq$ that of total $\mathrm{N}_{2} \mathrm{O}_{5}\left(\mathrm{IN}_{2} \mathrm{O}_{5}{ }^{-}+\mathrm{NO}_{3}{ }^{-}\right)\left(\mathrm{dV}_{50}=29.5 \pm 0.5 \mathrm{~V}\right)$ was assigned the same sensitivity as total $\mathrm{N}_{2} \mathrm{O}_{5}$ (i.e. the 'collision-limit' sensitivity). $\mathrm{Cl}_{2} \mathrm{O}$ and $\mathrm{NCl}_{3}$ had higher $\mathrm{dV}_{50}$ values than $\mathrm{N}_{2} \mathrm{O}_{5}$ during HOMEChem (36. $\pm 2 . \mathrm{V}$ and $37.1 \pm 0.3 \mathrm{~V}$, respectively), and were therefore assigned the collision-limit sensitivity. $\mathrm{NHCl}_{2}$ had a $\mathrm{dV}_{50}$ of $25.9 \pm 0.8 \mathrm{~V}$, and was assigned an estimated sensitivity of $10 \pm 10 \mathrm{~Hz} \mathrm{pptv}^{-1}$. The large magnitude of error in estimated $\mathrm{NHCl}_{2}$ sensitivity is associated with uncertainty in the $\mathrm{dV}_{50}$-sensitivity relationship model.

The calibrant compounds used in the generation of this sensitivity estimation model are representative of those whose $\mathrm{I}^{-}$adducts do not undergo substantial dissociation or fragmentation upon transmission through the TOF-CIMS. We note the abundance of $\mathrm{ICl}^{-}$in our I-TOF-CIMS spectra during bleach cleaning events at HOMEChem-likely a fragmentation product of labile chlorine-containing molecules initially bound to $\mathrm{I}$. This observation is consistent with Wong et al. ${ }^{22}$, who observed similar fragmentation in their I- TOF-CIMS spectra during their indoor bleach cleaning measurements. We hypothesize that I' adducts of many chlorine-containing molecules undergo fragmentation during their transmission through the TOF-CIMS, resulting in overestimated sensitivities (and therefore underestimated mixing ratios) from this model. Our model overestimates $\mathrm{HOCl}$ and $\mathrm{ClNO}_{2}$ sensitivities by 1 and 3 orders of magnitude, respectively, which could be driven by adduct fragmentation. Reported $\mathrm{Cl}_{2} \mathrm{O}, \mathrm{NHCl}_{2}$ and $\mathrm{NCl}_{3}$ mixing ratios could therefore also be further underestimated from this fragmentation. 


\section{Supporting Figures}

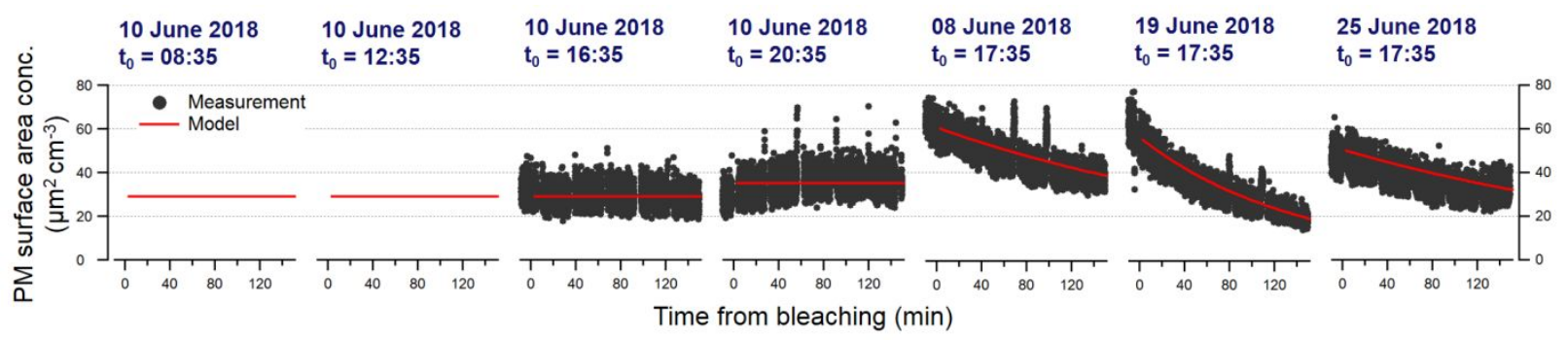

Figure S1. Measured indoor particulate matter (PM) surface area concentrations during various bleach cleaning experiments performed at HOMEChem (black markers). Red traces represent corresponding kinetic modeling results. $t_{0}$ indicates local times at which bleach mopping experiments began. 

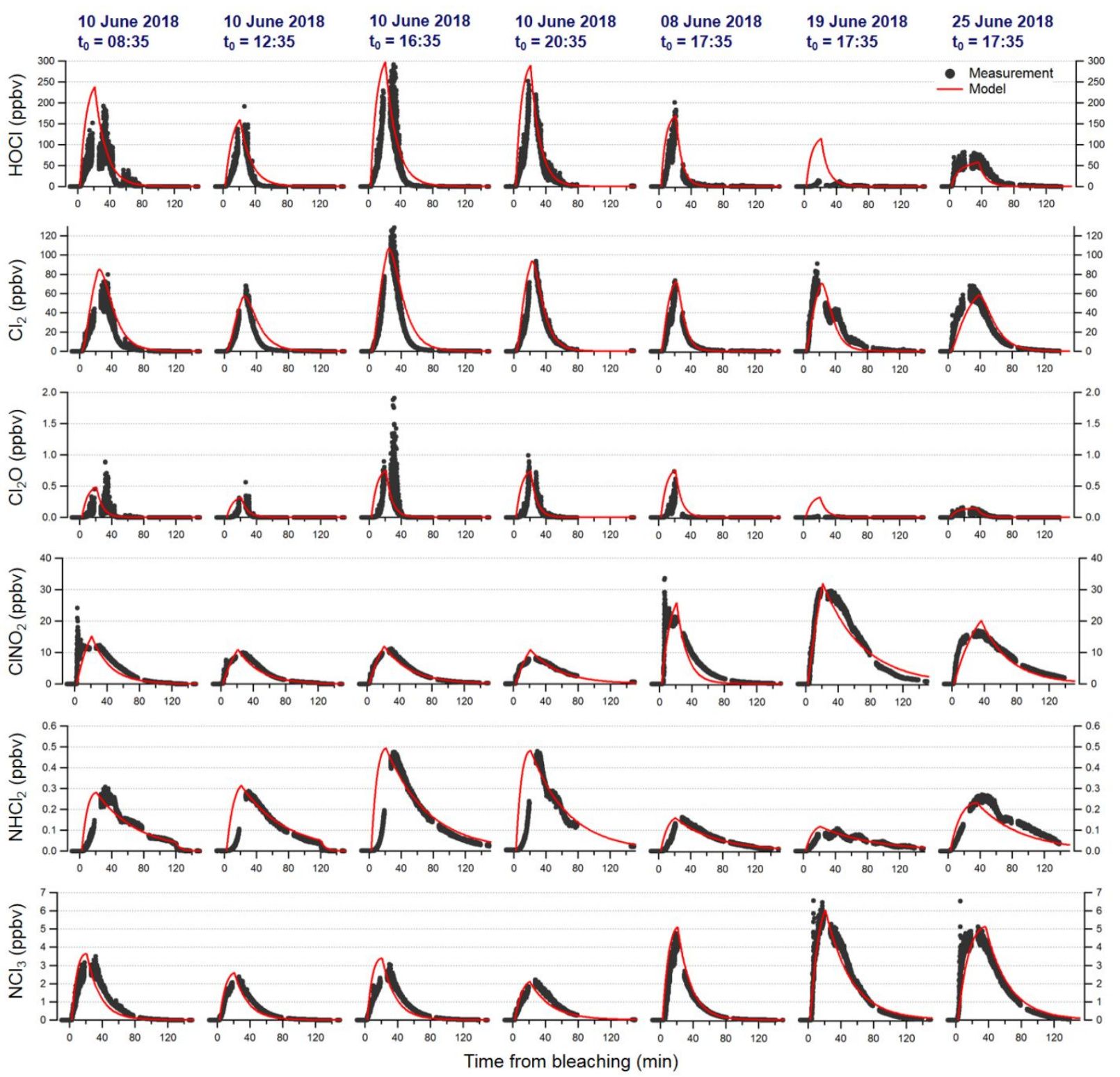

Figure S2. Measured indoor mixing ratios for $\mathrm{HOCl}, \mathrm{Cl}_{2}, \mathrm{Cl}_{2} \mathrm{O}, \mathrm{ClNO}_{2}, \mathrm{NHCl}_{2}$, and $\mathrm{NCl}_{3}$ during various bleach cleaning experiments performed at HOMEChem (black markers). Red traces represent corresponding kinetic modeling results. $t_{0}$ indicates local times at which bleach mopping experiments began. 

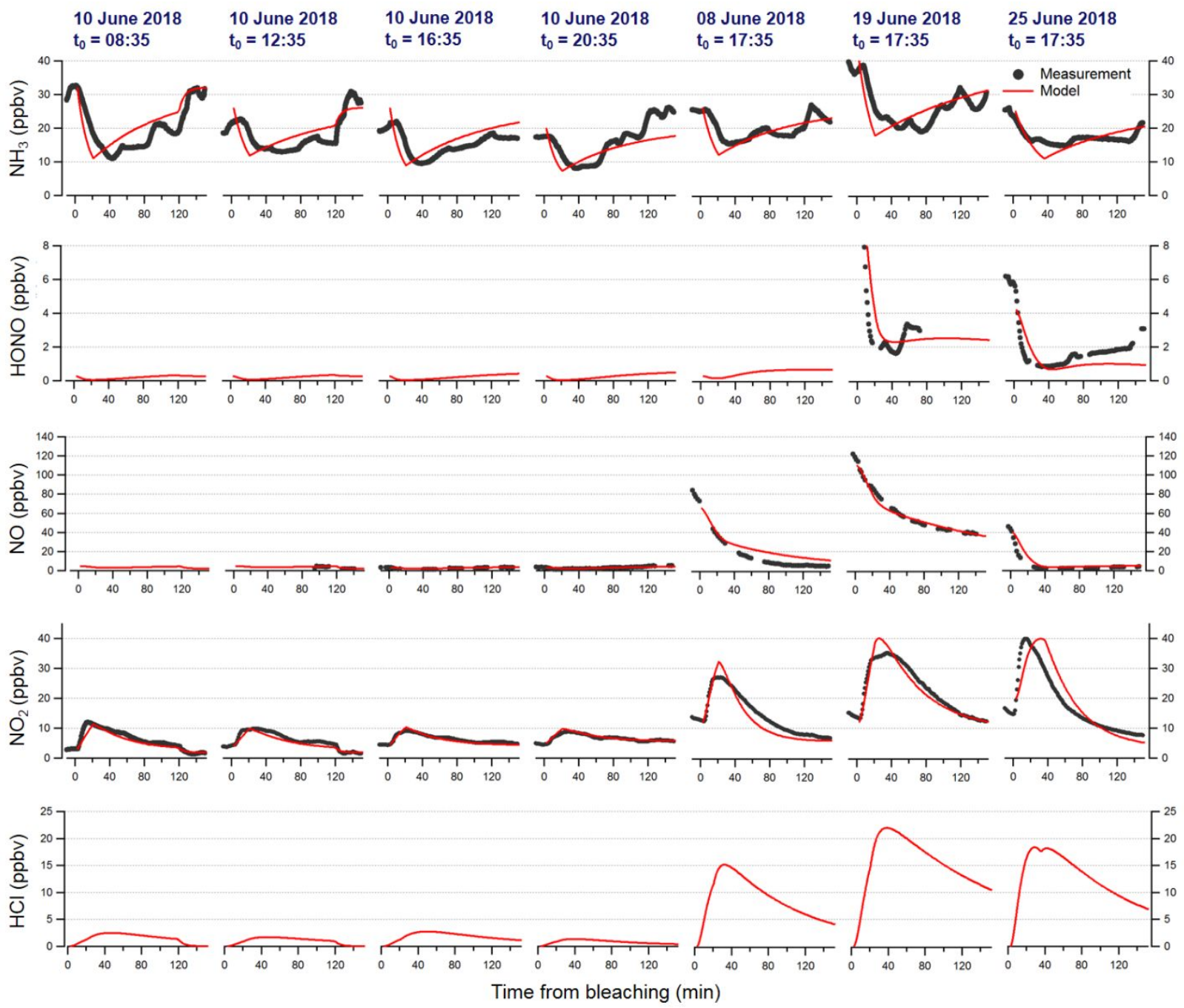

Figure S3. Measured indoor mixing ratios for $\mathrm{NH}_{3}, \mathrm{HONO}, \mathrm{NO}$, and $\mathrm{NO}_{2}$ during various bleach cleaning experiments performed at HOMEChem (black markers). Red traces represent kinetic modeling results for measured species, as well as predicted $\mathrm{HCl}$ mixing ratios. $t_{0}$ indicates local times at which bleach mopping experiments began. 


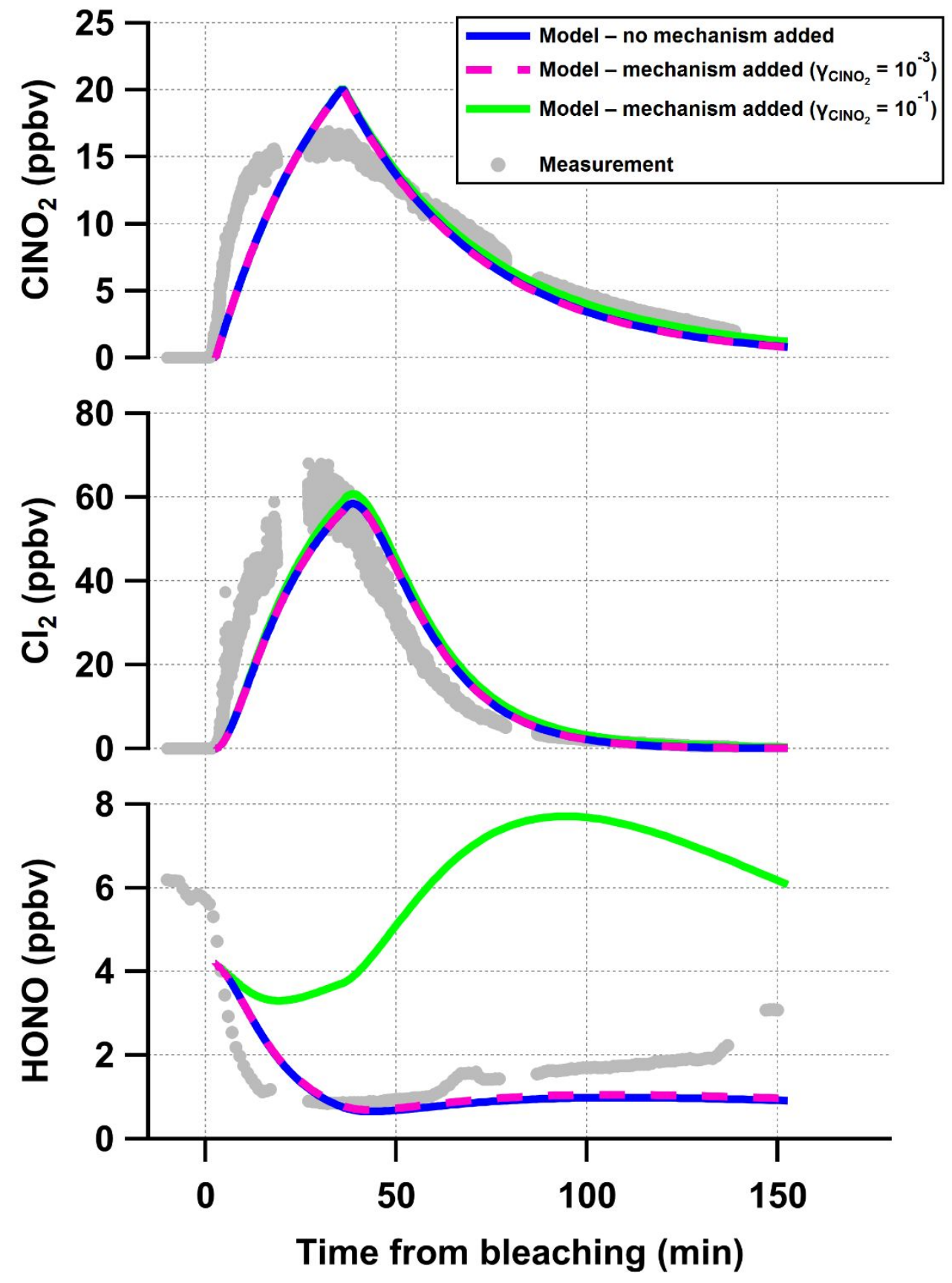

Figure S4. Kinetic model sensitivity test comparing indoor $\mathrm{CINO}_{2}, \mathrm{Cl}_{2}$, and $\mathrm{HONO}$ mixing ratios during the inclusion of a heterogeneous $\mathrm{ClNO}_{2}$ loss mechanism $\left(\mathrm{ClNO}_{2}+\mathrm{H}^{+}+\mathrm{Cl}^{-} \rightarrow \mathrm{Cl}_{2}+\mathrm{HONO}\right)$ during a bleach cleaning experiment on 25 June 2018 at HOMEChem. Solid blue trace represents model results excluding this mechanism. Dashed pink and solid green traces represents model results including this mechanism using uptake coefficients $\left(\gamma_{\mathrm{CINO} 2}\right)$ of $10^{-3}$ and $10^{-1}$, respectively. Grey markers represent HOMEChem measurement data. Bleach cleaning was performed at 17:35 local time, and lasted approximately 10 minutes. 


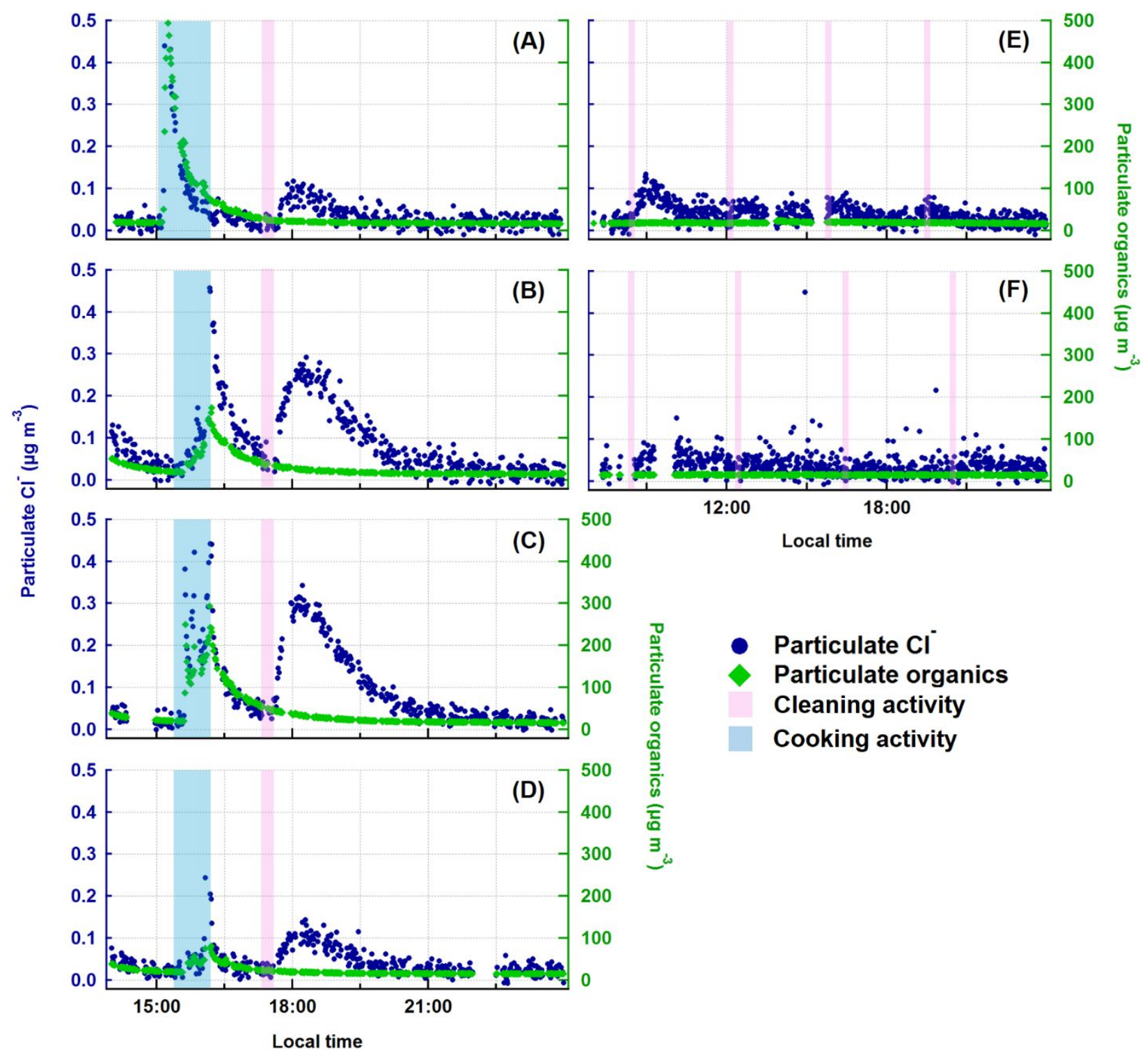

Figure S5. Indoor particulate $\mathrm{Cl}^{-}$(blue markers) and organic (green markers) mass concentrations during layered experiments on (A) 08, (B) 19, (C) 21, and (D) 25 June 2018; and sequential experiments on (E) 07 and (F) 10 June 2018. Shaded pink and blue regions correspond to local time during which bleach cleaning and cooking events took place, respectively. We use particulate organic mass concentration here as a proxy for total indoor PM mass concentration. 

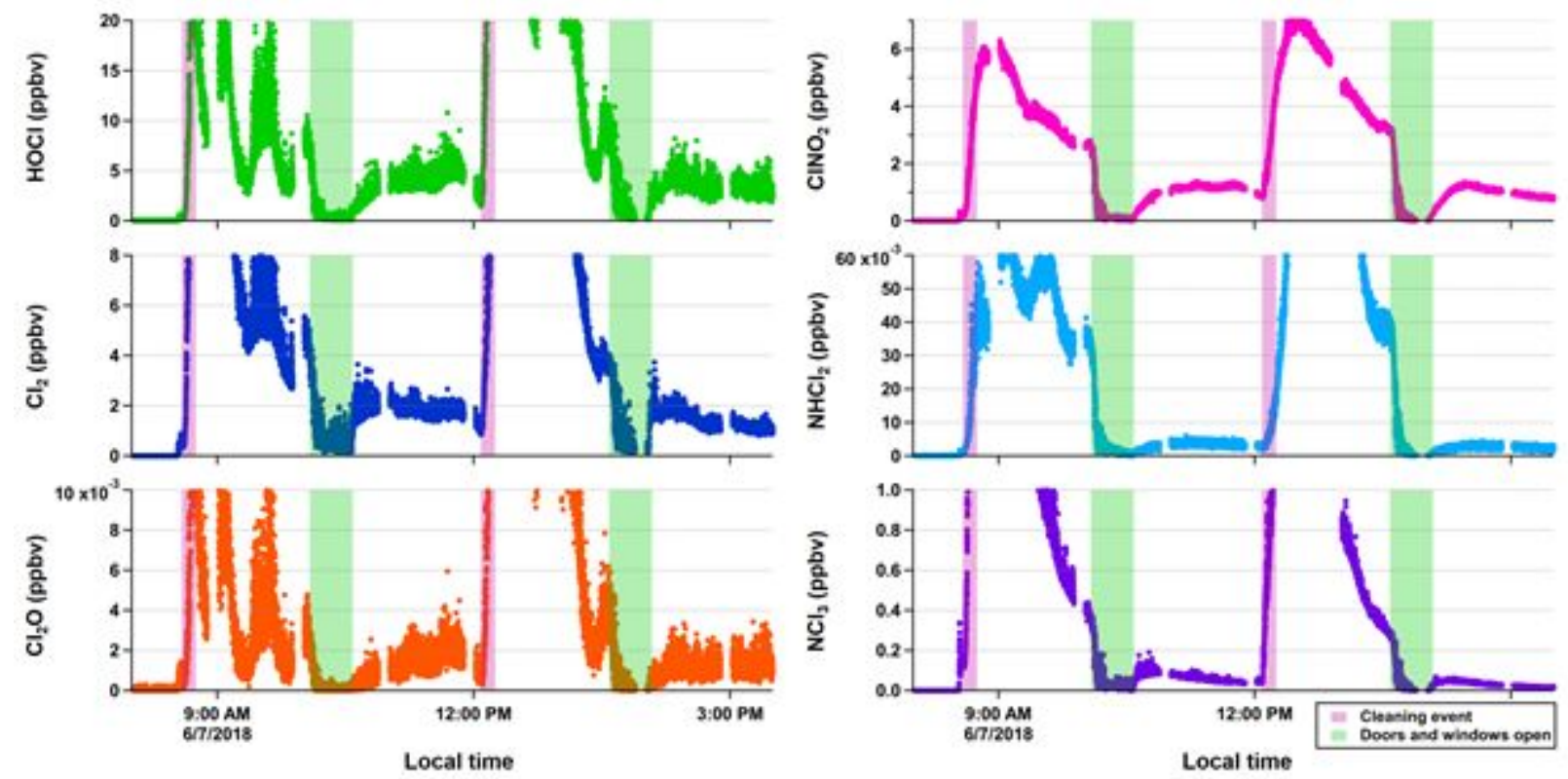

Figure S6. Indoor mixing ratio time series data (colored markers) for $\mathrm{HOCl}, \mathrm{Cl}_{2}, \mathrm{Cl}_{2} \mathrm{O}, \mathrm{ClNO}_{2}, \mathrm{NHCl}_{2}$, and $\mathrm{NCl}_{3}$ during a bleach cleaning experiment on 07 June 2018. Shaded pink and green regions correspond to local time during which bleach cleaning and door/window opening took place, respectively. 

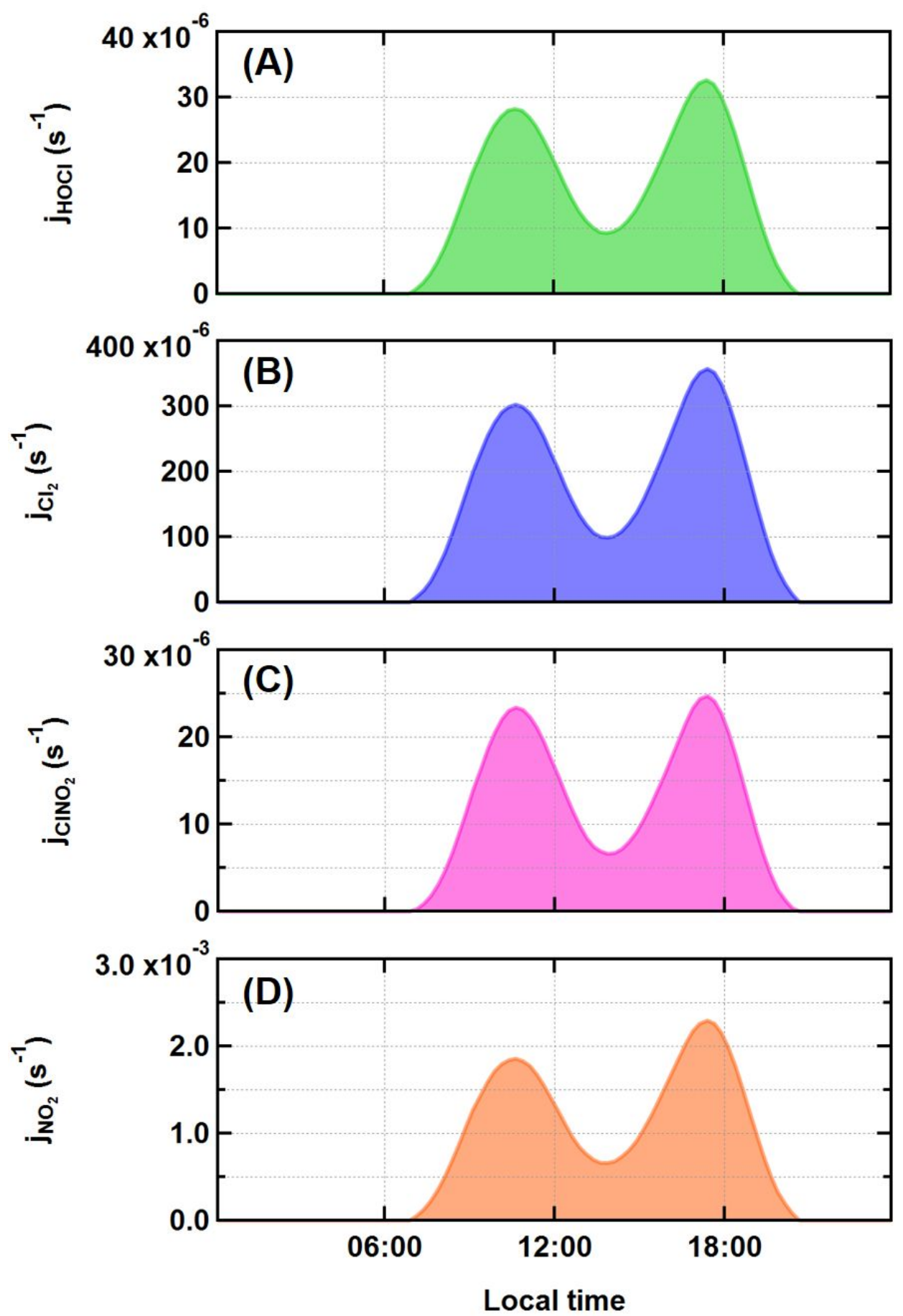

Figure S7. Upper-bound diel profiles of indoor photolysis rates for (A) $\mathrm{HOCl},(B) \mathrm{Cl}_{2}$, (C) $\mathrm{ClNO}_{2}$, and (D) $\mathrm{NO}_{2}$ for the duration of HOMEChem. 

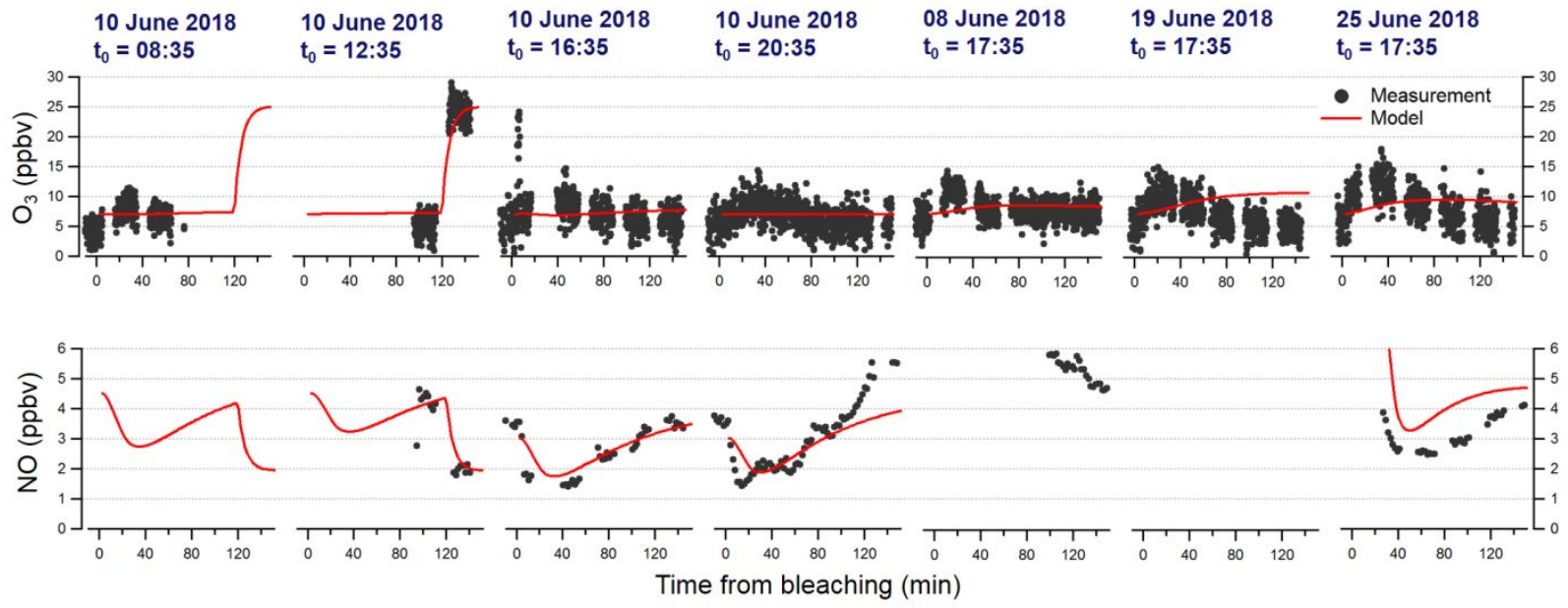

Figure S8. Measured indoor mixing ratios for $\mathrm{O}_{3}$ and $\mathrm{NO}$ during various bleach cleaning experiments performed at HOMEChem (black markers). Red traces represent corresponding kinetic modeling results. $t_{0}$ indicates local times at which bleach mopping experiments began. Note the different scale used for NO here compared to Figure S3. 
Shared ambient sampling/standard addition

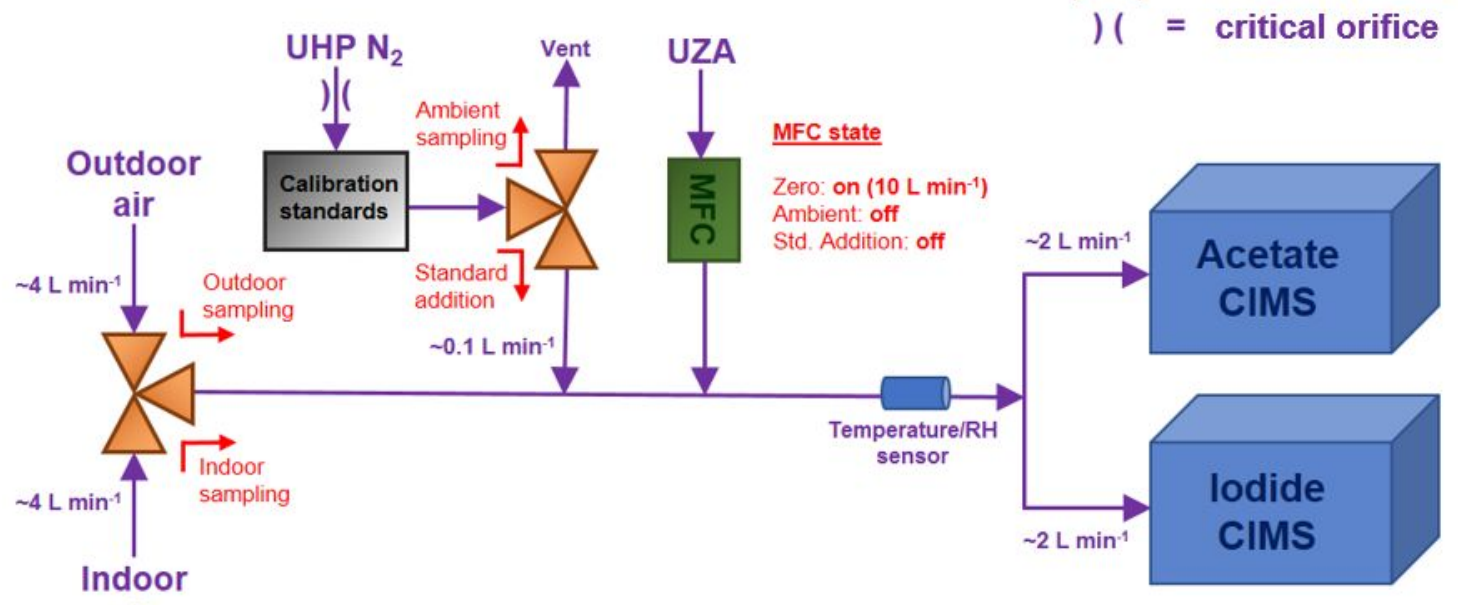

air

\section{External standard calibration}

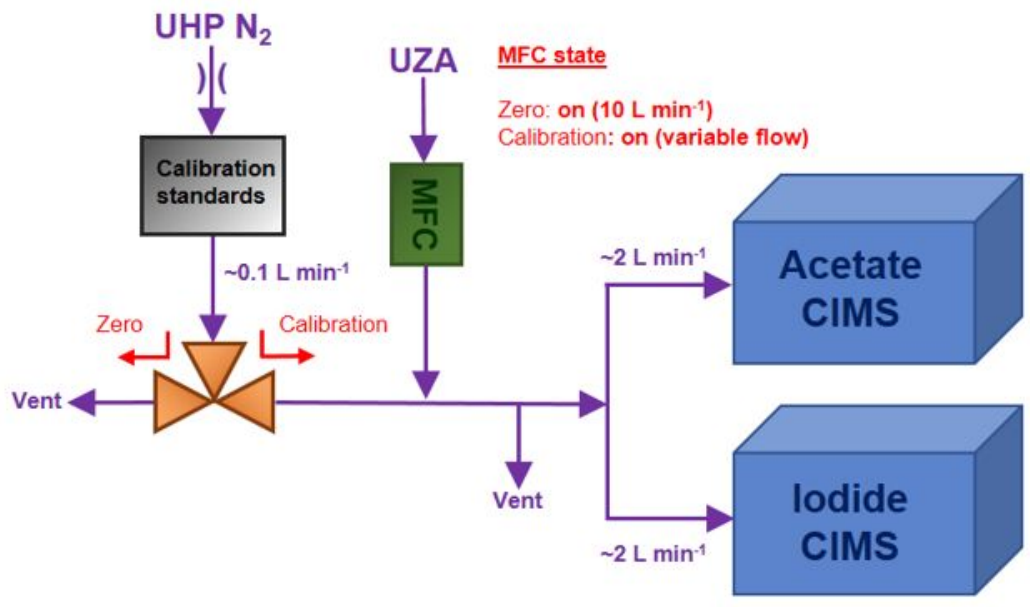

Figure S9. Schematic of shared inlet and calibration system used during HOMEChem during ambient sampling/standard addition (top), and external standard calibration regimes (bottom). Red arrows indicate direction of three-way valves during different sampling/calibration regimes. MFC = mass-flow controller. 


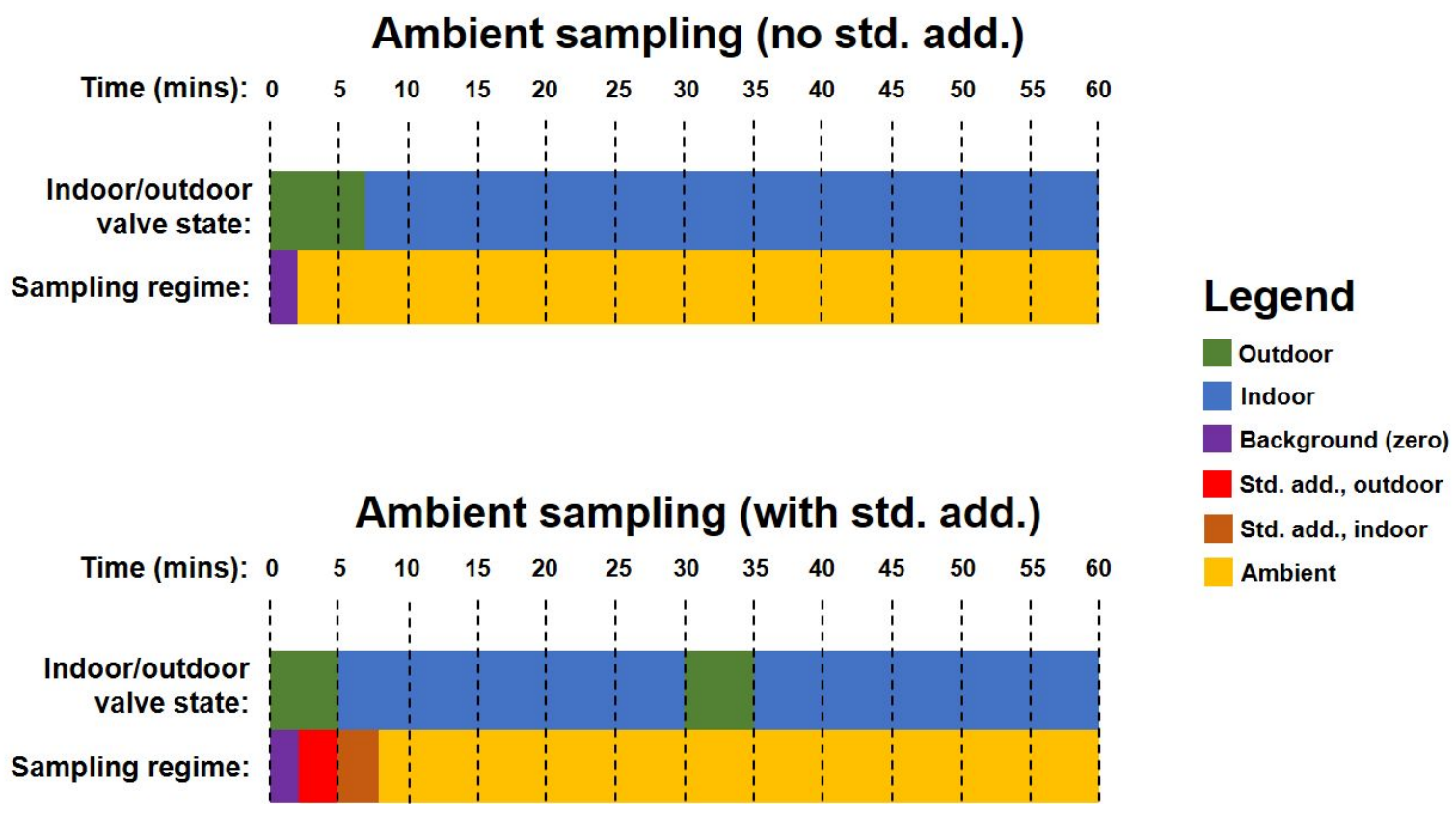

Figure S10. Timing scheme for instrumental backgrounds and indoor/outdoor ambient sampling without (top) and with (bottom) standard additions (abbreviated here as "std. add.") included. 

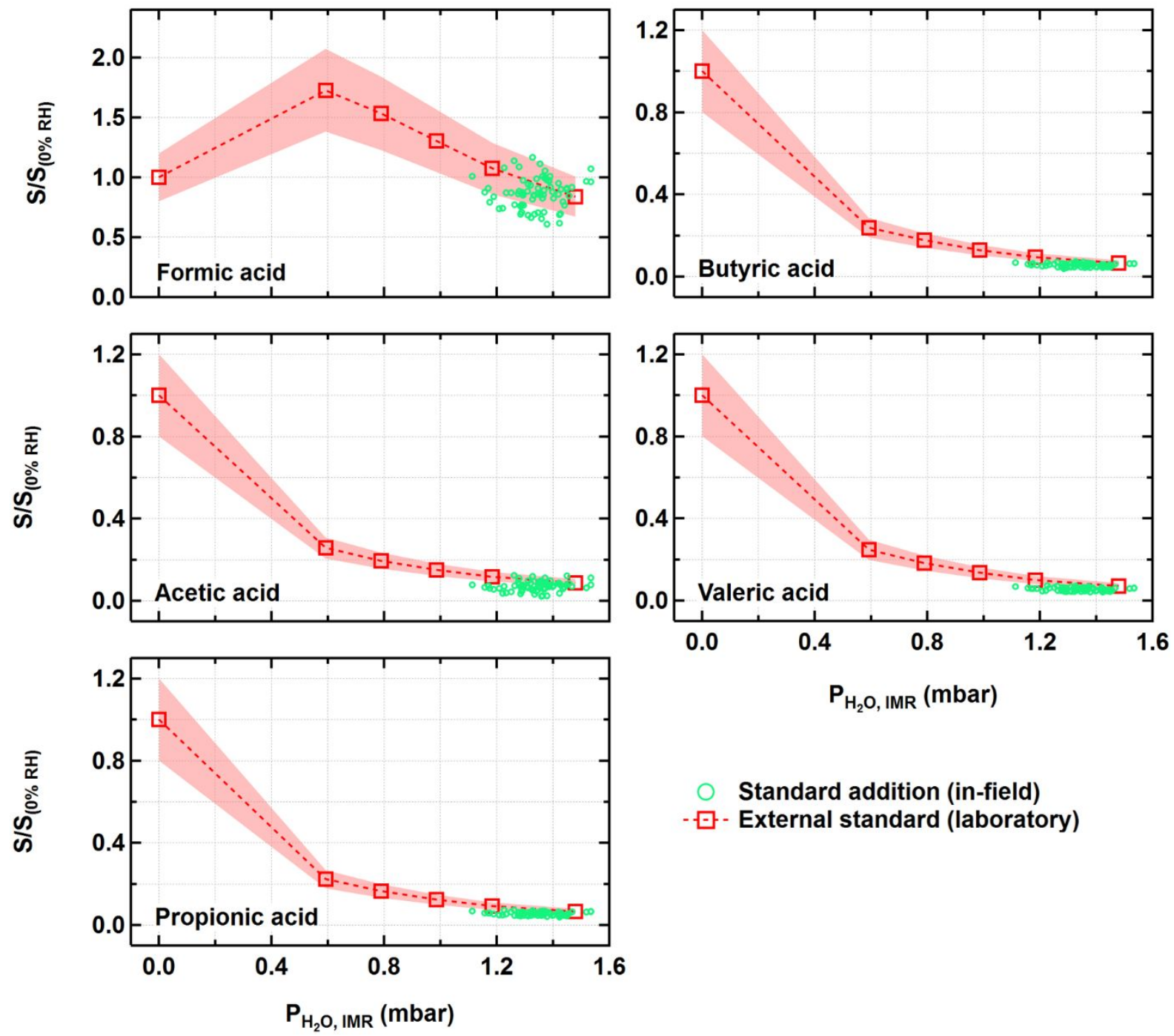

Standard addition (in-field)

- - - External standard (laboratory)

Figure S11. Standard addition I- TOF-CIMS sensitivities from HOMEChem (green dots), and RH-dependent external standard I- CIMS sensitivities (red markers) for $\mathrm{C}_{1}-\mathrm{C}_{5}$ alkanoic acids, plotted as a function of water vapor partial pressure in the IMR $\left(\mathrm{P}_{\mathrm{H} 2 \mathrm{O}, \mathrm{IMR}}\right)$. Red markers and shaded regions represent means and uncertainties of triplicate external standard calibration sensitivity measurements. Here, sensitivities (S) are reported relative to CIMS

sensitivity at $0 \% \mathrm{RH}\left(\mathrm{S}_{(\mathrm{O} \% \mathrm{RH})}\right)$. 


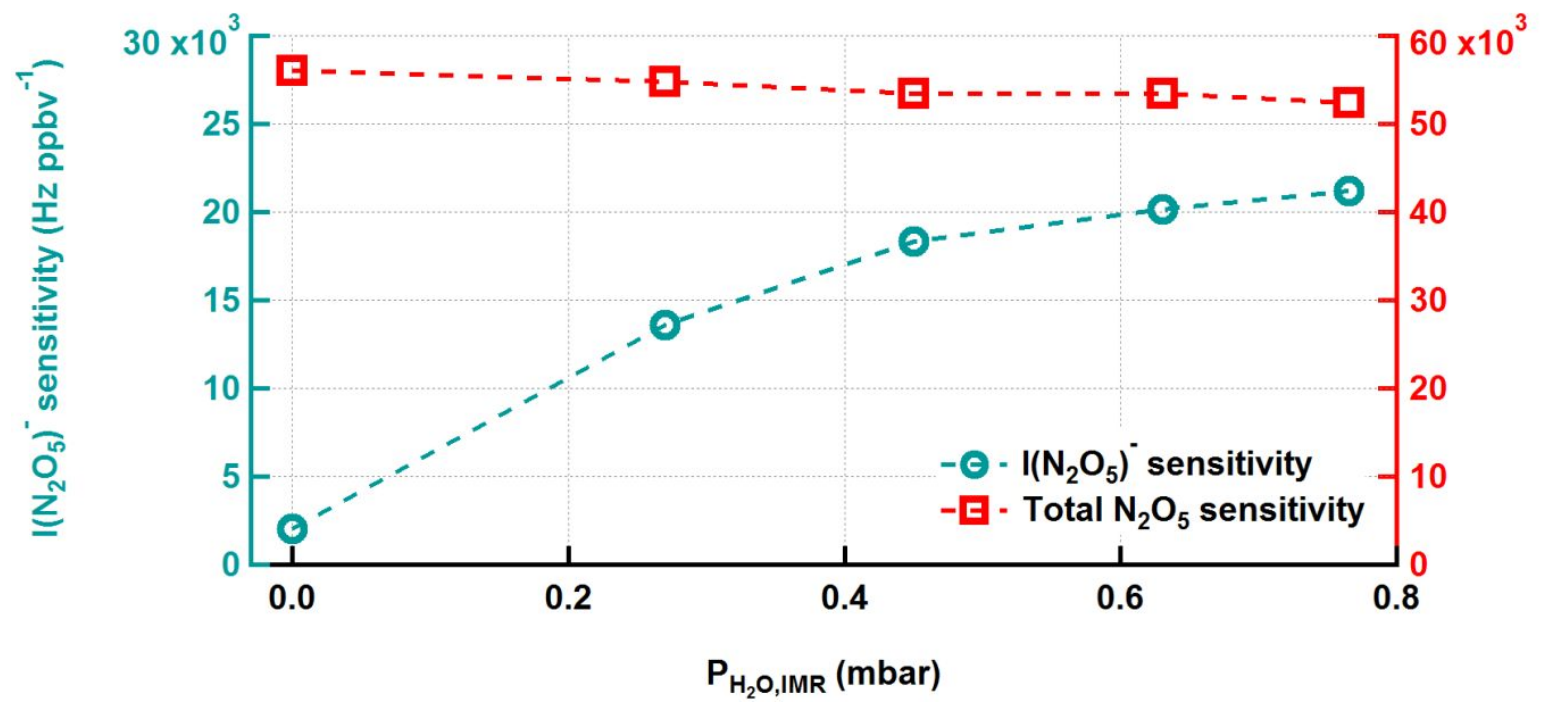

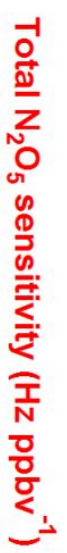

Figure S12. I- TOF-CIMS sensitivities for $\mathrm{IN}_{2} \mathrm{O}_{5}^{-}$(teal circles, left vertical axis) and total $\mathrm{N}_{2} \mathrm{O}_{5}$ (red squares, right vertical axis) measured as a function of water vapor partial pressure in the IMR $\left(\mathrm{P}_{\mathrm{H} 20, \mathrm{IMR}}\right)$. Markers represent means of each calibration. We exclude error bars for clarity. Here, 'total $\mathrm{N}_{2} \mathrm{O}_{5}$ ' corresponds to $\mathrm{IN}_{2} \mathrm{O}_{5}{ }^{-}+\mathrm{NO}_{3}$.

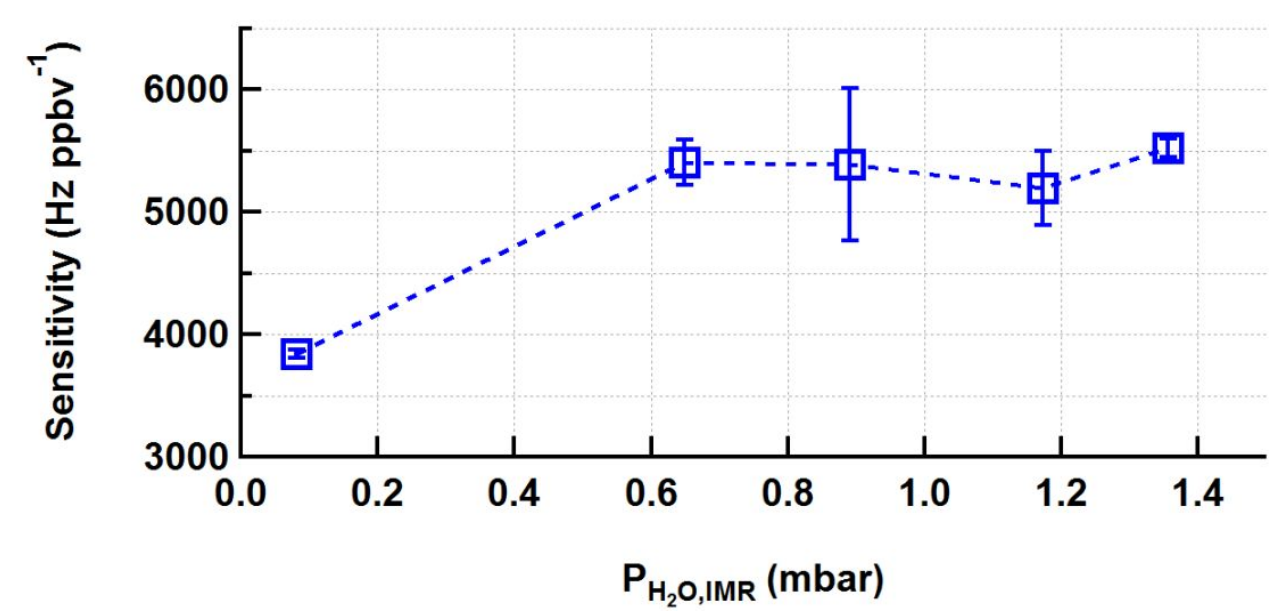

Figure S13. $\mathrm{CINO}_{2}$ I- TOF-CIMS sensitivities measured as a function of water vapor partial pressure in the IMR $\left(\mathrm{P}_{\mathrm{H} 2 \mathrm{O}, \mathrm{IMR}}\right)$. Markers and error bars represent means and uncertainties of each calibration. 


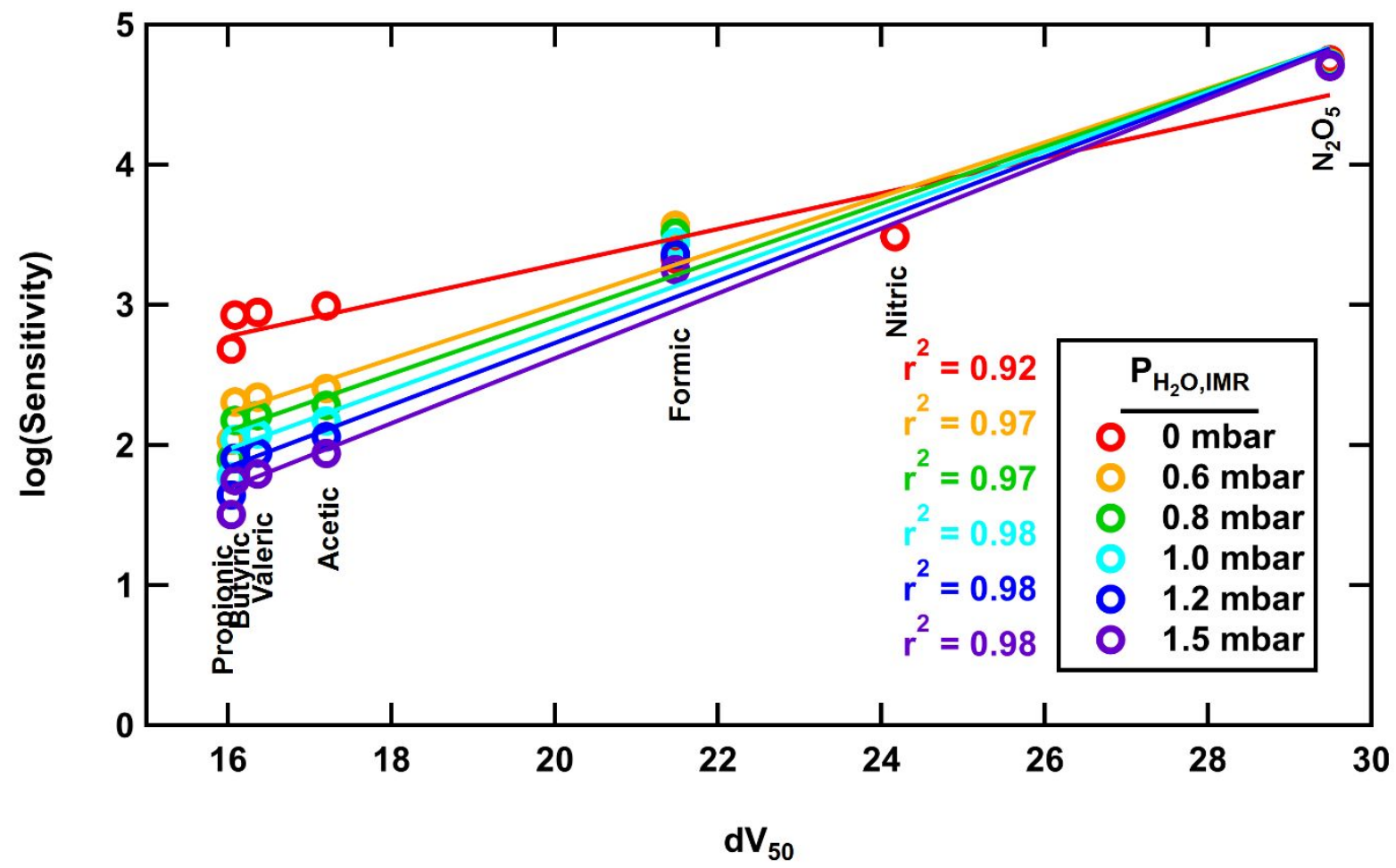

Figure S14. Relationship between the logarithm of I- TOF-CIMS sensitivity and $\mathrm{dV}_{50}$ for several calibrant compounds (colored markers). Solid colored traces represent linear fits to the data using a least orthogonal distance regression (ODR) fitting method. Markers, linear fits, and $r^{2}$ values are colored by $\mathrm{P}_{\mathrm{H} 2 \mathrm{O}, \mathrm{IMR}}$ values (see figure legend). $\mathrm{N}_{2} \mathrm{O}_{5}$ sensitivity corresponds to 'total $\mathrm{N}_{2} \mathrm{O}_{5}{ }^{\prime}\left(\mathrm{IN}_{2} \mathrm{O}_{5}{ }^{-}+\mathrm{NO}_{3}{ }^{-}\right)$. We are only able to report $\mathrm{HNO}_{3}$ sensitivity at $\mathrm{P}_{\mathrm{H} 2 \mathrm{O}, \mathrm{IMR}}=0$ mbar. Vertical text labels correspond to approximate locations of calibrant compounds in $\mathrm{dV}_{50} \mathrm{space}_{\text {. }}$ 

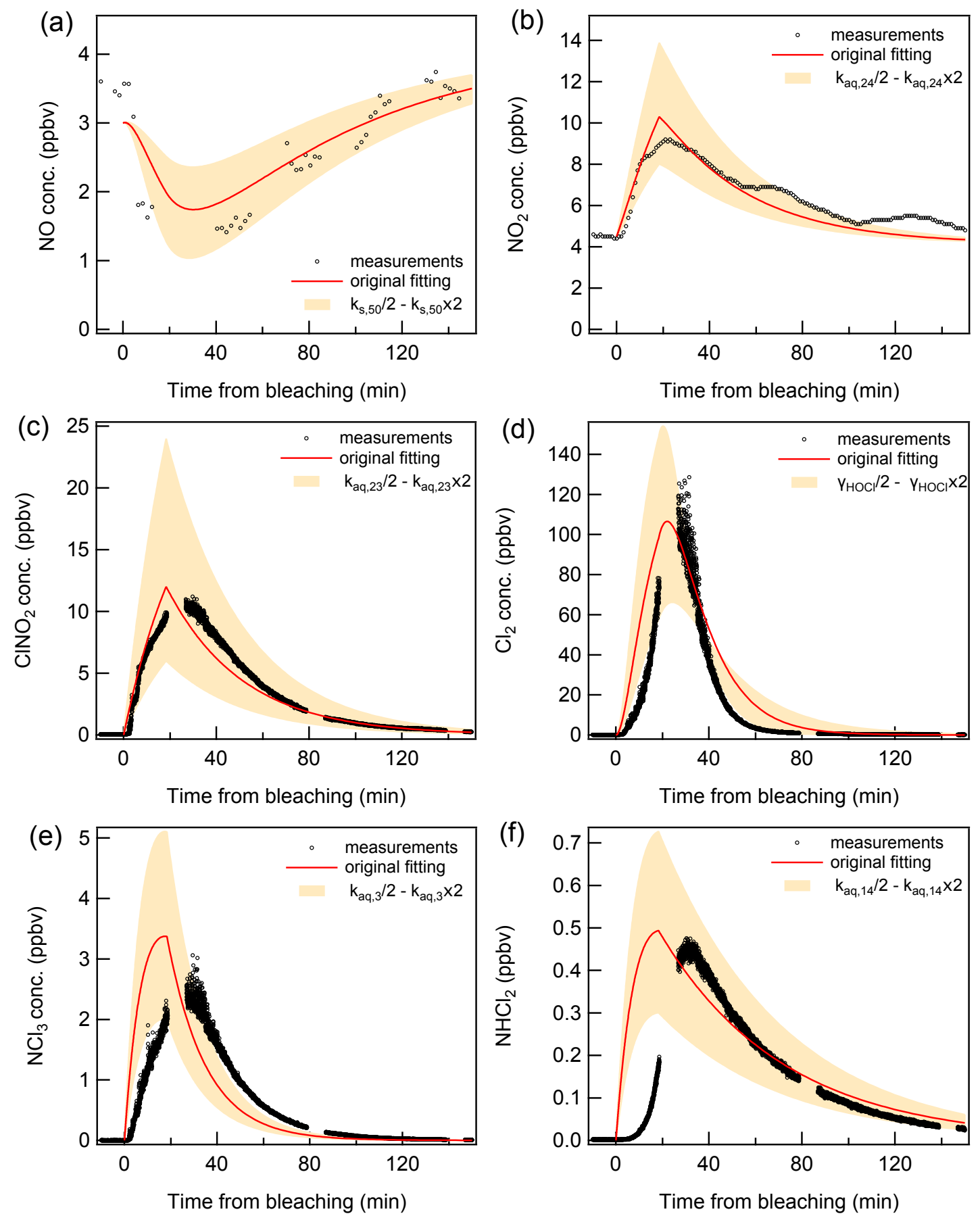

Figure S15. Sensitivity tests showing the impact of increasing or decreasing selected parameters on model outputs of gas-phase concentrations of selected chemical species. Parameters were typically varied by a factor of two. The target parameter and chosen range is shown in each sub-figure legend. For example, panel (d) shows the impact on $\mathrm{Cl}_{2}$ concentration from varying the uptake coefficient of $\mathrm{HOCl}$ by a factor of 2 (shaded yellow region) from the base case scenario (red line, corresponds to values summarized in Table S4). 


\section{Supporting Tables}

Table S1 - Aqueous chemical mechanisms in the applied bleach used in kinetic model.

\begin{tabular}{|c|c|c|c|}
\hline $\begin{array}{l}\text { Reaction } \\
\text { number }\end{array}$ & Reaction & Rate & $\begin{array}{l}\text { Reference } \\
\text { or } \\
\text { comment }\end{array}$ \\
\hline 1 & $\mathrm{NH}_{3}+\mathrm{HOCl} \rightarrow \mathrm{NH}_{2} \mathrm{Cl}+\mathrm{H}_{2} \mathrm{O}$ & $k_{\mathrm{aq}, 1}=6.9 \times 10^{-15} \mathrm{~cm}^{3} \mathrm{~s}^{-1}$ & $\begin{array}{l}\text { Jafvert and } \\
\text { Valentine }\end{array}$ \\
\hline 2 & $\mathrm{NH}_{2} \mathrm{Cl}+\mathrm{HOCl} \rightarrow \mathrm{NHCl}_{2}+\mathrm{H}_{2} \mathrm{O}$ & $k_{\mathrm{aq}, 2}=4.6 \times 10^{-17} \mathrm{~cm}^{3} \mathrm{~s}^{-1} *$ & $\begin{array}{l}\text { Jafvert and } \\
\text { Valentine }{ }^{23}\end{array}$ \\
\hline 3 & $\mathrm{NHCl}_{2}+\mathrm{HOCl} \rightarrow \mathrm{NCl}_{3}+\mathrm{H}_{2} \mathrm{O}$ & $k_{\mathrm{aq}, 3}=$ see Table $\mathrm{S} 4 * *$ & $\begin{array}{l}\text { Jafvert and } \\
\text { Valentine } 23\end{array}$ \\
\hline 4 & $\mathrm{NH}_{2} \mathrm{Cl}+\mathrm{H}_{2} \mathrm{O} \rightarrow \mathrm{HOCl}+\mathrm{NH}_{3}$ & $k_{\mathrm{aq}, 4}=2.1 \times 10^{-5} \mathrm{~s}^{-1}$ & $\begin{array}{l}\text { Jafvert and } \\
\text { Valentine }{ }^{23}\end{array}$ \\
\hline 5 & $\mathrm{NHCl}_{2}+\mathrm{H}_{2} \mathrm{O} \rightarrow \mathrm{HOCl}+\mathrm{NH}_{2} \mathrm{Cl}$ & $k_{\mathrm{aq}, 5}=6.4 \times 10^{-7} \mathrm{~s}^{-1}$ & $\begin{array}{l}\text { Jafvert and } \\
\text { Valentine }{ }^{23}\end{array}$ \\
\hline 6 & $\mathrm{NH}_{2} \mathrm{Cl}+\mathrm{NH}_{2} \mathrm{Cl}+\mathrm{H}^{+} \rightarrow \mathrm{NHCl}_{2}+\mathrm{NH}_{3}$ & $k_{\mathrm{aq}, 6}=1.9 \times 10^{-38} \mathrm{~cm}^{6} \mathrm{~s}^{-1}$ & $\begin{array}{l}\text { Jafvert and } \\
\text { Valentine }{ }^{23}\end{array}$ \\
\hline 7 & $\mathrm{NHCl}_{2}+\mathrm{NH}_{3}+\mathrm{H}^{+} \rightarrow \mathrm{NH}_{2} \mathrm{Cl}+\mathrm{NH}_{2} \mathrm{Cl}$ & $k_{\mathrm{aq}, 7}=1.7 \times 10^{-37} \mathrm{~cm}^{6} \mathrm{~s}^{-1}$ & $\begin{array}{l}\text { Jafvert and } \\
\text { Valentine }{ }^{23}\end{array}$ \\
\hline 8 & $\mathrm{NHCl}_{2}+\mathrm{OH}^{-} \rightarrow \mathrm{I}$ & $k_{\mathrm{aq}, 8}=1.9 \times 10^{-19} \mathrm{~cm}^{3} \mathrm{~s}^{-1}$ & $\begin{array}{l}\text { Jafvert and } \\
\text { Valentine }{ }^{23}\end{array}$ \\
\hline 9 & $\mathrm{I}+\mathrm{NHCl}_{2} \rightarrow \mathrm{HOCl}+$ Products & $k_{\mathrm{aq}, 9}=4.6 \times 10^{-17} \mathrm{~cm}^{3} \mathrm{~s}^{-1}$ & $\begin{array}{l}\text { Jafvert and } \\
\text { Valentine } 23\end{array}$ \\
\hline 10 & $\mathrm{I}+\mathrm{NH}_{2} \mathrm{Cl} \rightarrow$ Products & $k_{\mathrm{aq}, 10}=1.4 \times 10^{-17} \mathrm{~cm}^{3} \mathrm{~s}^{-1}$ & $\begin{array}{l}\text { Jafvert and } \\
\text { Valentine }^{23}\end{array}$ \\
\hline 11 & $\mathrm{NH}_{2} \mathrm{Cl}+\mathrm{NHCl}_{2} \rightarrow$ Products & $k_{\mathrm{aq}, 11}=2.5 \times 10^{-23} \mathrm{~cm}^{3} \mathrm{~s}^{-1}$ & $\begin{array}{l}\text { Jafvert and } \\
\text { Valentine }{ }^{23}\end{array}$ \\
\hline 12 & $\mathrm{NHCl}_{2}+\mathrm{NCl}_{3}+\mathrm{OH}^{-} \rightarrow 2 \mathrm{HOCl}+$ Products & $k_{\mathrm{aq}, 12}=1.5 \times 10^{-31} \mathrm{~cm}^{6} \mathrm{~s}^{-1}$ & $\begin{array}{l}\text { Jafvert and } \\
\text { Valentine }{ }^{23}\end{array}$ \\
\hline 13 & $\mathrm{NH}_{2} \mathrm{Cl}+\mathrm{NCl}_{3}+\mathrm{OH}^{-} \rightarrow \mathrm{HOCl}+$ Products & $k_{\mathrm{aq}, 13}=3.8 \times 10^{-33} \mathrm{~cm}^{6} \mathrm{~s}^{-1}$ & $\begin{array}{l}\text { Jafvert and } \\
\text { Valentine }\end{array}$ \\
\hline $14^{* * *}$ & $\mathrm{NHCl}_{2}+2 \mathrm{HOCl}+\mathrm{H}_{2} \mathrm{O} \rightarrow \mathrm{HNO}_{3}+4 \mathrm{HCl}$ & $k_{\mathrm{aq}, 14}=$ see Table S4 & $\begin{array}{l}\text { Jafvert and } \\
\text { Valentine }\end{array}$ \\
\hline 15 & $\mathrm{OCl}^{-}+\mathrm{H}^{+} \rightarrow \mathrm{HOCl}$ & $k_{\mathrm{aq}, 15}=1.0 \times 10^{-11} \mathrm{~cm}^{3} \mathrm{~s}^{-1}$ & $\begin{array}{l}\text { assumed to } \\
\text { be fast }\end{array}$ \\
\hline 16 & $\mathrm{HOCl} \rightarrow \mathrm{H}^{+}+\mathrm{OCl}^{-}$ & $\begin{array}{c}k_{\mathrm{aq}, 16}=k_{\mathrm{aq}, 15} \times\left(6.02 \times 10^{23} /\right. \\
1000) \times 2.9 \times 10^{-8} \mathrm{~s}^{-1}\end{array}$ & $\begin{array}{c}\text { based on a } \mathrm{K}_{\mathrm{a}} \\
\text { value of } 2.9 \times \\
10^{-8} ; \\
\text { Deborde and } \\
\text { Von Gunten }\end{array}$ \\
\hline 17 & $\mathrm{HOCl}+\mathrm{H}^{+}+\mathrm{Cl}^{-} \rightarrow \mathrm{Cl}_{2}+\mathrm{H}_{2} \mathrm{O}$ & $k_{\mathrm{aq}, 17}=1.2 \times 10^{-37} \mathrm{~cm}^{6} \mathrm{~s}^{-1}$ & $\begin{array}{l}\text { Deborde and } \\
\text { Von Gunten }{ }^{24}\end{array}$ \\
\hline 18 & $\mathrm{H}_{2} \mathrm{O}+\mathrm{Cl}_{2} \rightarrow \mathrm{HOCl}+\mathrm{H}^{+}+\mathrm{Cl}^{-}$ & $k_{\mathrm{aq}, 18}=22.3 \mathrm{~s}^{-1}$ & $\begin{array}{l}\text { Deborde and } \\
\text { Von Gunten }\end{array}$ \\
\hline 19 & $\mathrm{H}^{+}+\mathrm{Cl}^{-} \rightarrow \mathrm{HCl}$ & $k_{\mathrm{aq}, 19}=1.0 \times 10^{-11} \mathrm{~cm}^{3} \mathrm{~s}^{-1}$ & $\begin{array}{l}\text { assumed to } \\
\text { be fast }\end{array}$ \\
\hline 20 & $\mathrm{HCl} \rightarrow \mathrm{H}^{+}+\mathrm{Cl}^{-}$ & $\begin{array}{c}k_{\mathrm{aq}, 20}=k_{\mathrm{aq}, 19} \times\left(6.02 \times 10^{23} /\right. \\
1000) \times 1.3 \times 10^{6} \mathrm{~s}^{-1}\end{array}$ & $\begin{array}{l}\text { based on a } \mathrm{K}_{\mathrm{a}} \\
\text { value of } 1.3 \times \\
10^{6}\end{array}$ \\
\hline
\end{tabular}


21

$2 \mathrm{Cl}_{2} \mathrm{O}+\mathrm{H}_{2} \mathrm{O} \rightarrow \mathrm{HOCl}+\mathrm{HOCl}$

$$
\mathrm{HOCl}+\mathrm{HOCl} \rightarrow \mathrm{Cl}_{2} \mathrm{O}+\mathrm{H}_{2} \mathrm{O}
$$

$$
\mathrm{Cl}_{2} \mathrm{O}+\mathrm{H}_{2} \mathrm{O} \rightarrow \mathrm{HOCl}+\mathrm{HOCl}
$$

$$
\begin{gathered}
k_{\mathrm{aq}, 21}=3.0 \times 10^{-23} \mathrm{~cm}^{3} \mathrm{~s}^{-1} \\
k_{\mathrm{aq}, 22}=k_{\mathrm{aq}, 21} \times\left(6.02 \times 10^{23} /\right. \\
1000) \times 8.7 \times 10^{-3} \mathrm{~s}^{-1}
\end{gathered}
$$

fitting parameter based on a $\mathrm{K}_{\mathrm{a}}$ value of $8.7 \times$ $10^{-3}$; Deborde and Von Gunten ${ }^{24}$ Eiserich et Frenzel et al. ${ }^{26}$ al. ${ }^{25}$
23
$\mathrm{HOCl}+\left(\mathrm{NO}_{2}^{-}\right) \rightarrow \mathrm{ClNO}_{2}+\mathrm{OH}^{-}$
$k_{\mathrm{aq}, 23}=$ see Table $\mathrm{S} 4$
$k_{\text {aq }, 24}=$ see Table $\mathrm{S} 4$
$\mathrm{ClNO}_{2}+\left(\mathrm{NO}_{2}^{-}\right) \rightarrow 2 \mathrm{NO}_{2}+\mathrm{Cl}^{-}$

\begin{abstract}
* Increased from a literature value of $4.6 \times 10^{-19} \mathrm{~cm}^{3} \mathrm{~s}^{-1}$ in order to fit the data and in order to not be significantly lower than $k_{\mathrm{aq}, 3}$. This may be due to specific experimental conditions affecting bleach solution $\mathrm{pH}$ and/or composition.
\end{abstract}

** The literature value was $4.6 \times 10^{-37}\left[\mathrm{OCl}^{-}\right]+9.0 \times 10^{-33}\left[\mathrm{OH}^{-}\right] \mathrm{cm}^{3} \mathrm{~s}^{-1}$ but was simplified and varied until the data

\begin{tabular}{|c|c|c|c|}
\hline $\begin{array}{l}\text { Reaction } \\
\text { number }\end{array}$ & Reaction & Rate & $\begin{array}{l}\text { Reference or } \\
\text { comment }\end{array}$ \\
\hline 1 & $\mathrm{Cl}_{2}+h v \rightarrow 2 \mathrm{Cl}$ & $j_{\mathrm{C} 12}=$ see Table $\mathrm{S} 4$ & Xue et al. ${ }^{3}$ \\
\hline 2 & $\mathrm{HOCl}+h v \rightarrow \mathrm{OH}+\mathrm{Cl}$ & $j_{\text {HOCl }}=$ see Table $S 4$ & Xue et al. ${ }^{3}$ \\
\hline 3 & $\mathrm{ClNO}_{2}+h v \rightarrow \mathrm{NO}_{2}+\mathrm{Cl}$ & $j_{\mathrm{CINO2}}=$ see Table S4 & Xue et al. ${ }^{3}$ \\
\hline 4 & $\mathrm{ClONO}_{2}+h v \rightarrow \mathrm{NO}_{3}+\mathrm{Cl}$ & $k_{\mathrm{g}, 4}=0.83 \times j_{\mathrm{CINO} 2}$ & Xue et al. ${ }^{3}$ \\
\hline 5 & $\mathrm{ClONO}_{2}+h v \rightarrow \mathrm{NO}_{2}+\mathrm{ClO}$ & $k_{\mathrm{g}, 5}=0.17 \times j_{\mathrm{CINO} 2}$ & Xue et al. ${ }^{3}$ \\
\hline 6 & $\mathrm{NO}_{2}+\mathrm{NO}_{3} \rightarrow \mathrm{N}_{2} \mathrm{O}_{5}$ & $k_{\mathrm{g}, 6}=1.9 \times 10^{-12} \mathrm{~cm}^{3} \mathrm{~s}^{-1}$ & Atkinson et al. ${ }^{27}$ \\
\hline 7 & $\mathrm{~N}_{2} \mathrm{O}_{5} \rightarrow \mathrm{NO}_{2}+\mathrm{NO}_{3}$ & $k_{\mathrm{g}, 7}=6.9 \times 10^{-2} \mathrm{~s}^{-1}$ & Atkinson et al. ${ }^{27}$ \\
\hline 8 & $\mathrm{Cl}+\mathrm{O}_{3} \rightarrow \mathrm{ClO}+\mathrm{O}_{2}$ & $\begin{array}{c}k_{\mathrm{g}, 8}=2.8 \times 10^{-11} \times \exp (-250 / T) \mathrm{cm}^{3} \\
\mathrm{~s}^{-1}\end{array}$ & Xue et al. ${ }^{3}$ \\
\hline 9 & $\mathrm{Cl}+\mathrm{HO}_{2} \rightarrow \mathrm{HCl}+\mathrm{O}_{2}$ & $k_{g, 9}=3.5 \times 10^{-11} \mathrm{~cm}^{3} \mathrm{~s}^{-1}$ & Xue et al. ${ }^{3}$ \\
\hline 10 & $\mathrm{Cl}+\mathrm{HO}_{2} \rightarrow \mathrm{ClO}+\mathrm{OH}$ & $\begin{array}{c}k_{\mathrm{g}, 10}=7.5 \times 10^{-11} \times \exp (-620 / T) \\
\mathrm{cm}^{3} \mathrm{~s}^{-1}\end{array}$ & Xue et al. ${ }^{3}$ \\
\hline 11 & $\mathrm{Cl}+\mathrm{H}_{2} \mathrm{O}_{2} \rightarrow \mathrm{HCl}+\mathrm{HO}_{2}$ & $\begin{array}{c}k_{\mathrm{g}, 11}=1.1 \times 10^{-11} \times \exp (-980 / T) \\
\mathrm{cm}^{3} \mathrm{~s}^{-1}\end{array}$ & Xue et al. ${ }^{3}$ \\
\hline 12 & $\mathrm{Cl}+\mathrm{NO}_{3} \rightarrow \mathrm{NO}_{2}+\mathrm{ClO}$ & $k_{\mathrm{g}, 12}=2.4 \times 10^{-11} \mathrm{~cm}^{3} \mathrm{~s}^{-1}$ & Xue et al. ${ }^{3}$ \\
\hline 13 & $\mathrm{Cl}+\mathrm{ClONO}_{2} \rightarrow \mathrm{Cl}_{2}+\mathrm{NO}_{3}$ & $\begin{array}{c}k_{\mathrm{g}, 13}=6.2 \times 10^{-12} \times \exp (-145 / T) \\
\mathrm{cm}^{3} \mathrm{~s}^{-1}\end{array}$ & Xue et al. ${ }^{3}$ \\
\hline 14 & $\mathrm{OH}+\mathrm{HCl} \rightarrow \mathrm{Cl}+\mathrm{H}_{2} \mathrm{O}$ & $\begin{array}{c}k_{\mathrm{g}, 14}=1.7 \times 10^{-12} \times \exp (-230 / T) \\
\mathrm{cm}^{3} \mathrm{~s}^{-1}\end{array}$ & Xue et al. ${ }^{3}$ \\
\hline
\end{tabular}
could be fitted as shown in Table $S 4$.

*** The rate expression is $k_{\mathrm{aq}, 14}\left[\mathrm{NHCl}_{2}\right]\left[\mathrm{OCl}^{-}\right] . k_{\mathrm{aq}, 14}$ was varied around the literature value of $3.8 \times 10^{-19} \mathrm{~cm}^{3} \mathrm{~s}^{-1}$ until the data could be fitted and values are close to the original value.

\section{Table S2 - Gas-phase and heterogeneous chemistry used in kinetic model.}




\begin{tabular}{|c|c|c|c|}
\hline 15 & $\mathrm{OH}+\mathrm{Cl}_{2} \rightarrow \mathrm{HOCl}+\mathrm{Cl}$ & $\begin{array}{c}k_{\mathrm{g}, 15}=3.6 \times 10^{-12} \times \exp (-1200 / T) \\
\mathrm{cm}^{3} \mathrm{~s}^{-1}\end{array}$ & Xue et al. ${ }^{3}$ \\
\hline 16 & $\mathrm{OH}+\mathrm{HOCl} \rightarrow \mathrm{ClO}+\mathrm{H}_{2} \mathrm{O}$ & $k_{\mathrm{g}, 16}=5.0 \times 10^{-13} \mathrm{~cm}^{3} \mathrm{~s}^{-1}$ & Xue et al. ${ }^{3}$ \\
\hline 17 & $\mathrm{OH}+\mathrm{ClO} \rightarrow \mathrm{HO}_{2}+\mathrm{Cl}$ & $k_{\mathrm{g}, 17}=1.8 \times 10^{-11} \mathrm{~cm}^{3} \mathrm{~s}^{-1}$ & Xue et al. ${ }^{3}$ \\
\hline 18 & $\mathrm{OH}+\mathrm{ClO} \rightarrow \mathrm{HCl}+\mathrm{O}_{2}$ & $k_{\mathrm{g}, 18}=1.2 \times 10^{-12} \mathrm{~cm}^{3} \mathrm{~s}^{-1}$ & Xue et al. ${ }^{3}$ \\
\hline 19 & $\mathrm{ClO}+\mathrm{NO}_{2} \rightarrow \mathrm{ClONO}_{2}$ & $k_{\mathrm{g}, 19}=2.0 \times 10^{-11} \mathrm{~cm}^{3} \mathrm{~s}^{-1} *$ & Xue et al. ${ }^{3}$ \\
\hline 20 & $\mathrm{ClO}+\mathrm{HO}_{2} \rightarrow \mathrm{HOCl}+\mathrm{O}_{2}$ & $\begin{array}{c}k_{\mathrm{g}, 20}=2.2 \times 10^{-12} \times \exp (340 / T) \mathrm{cm}^{3} \\
\mathrm{~s}^{-1}\end{array}$ & Xue et al. ${ }^{3}$ \\
\hline 21 & $\mathrm{ClO}+\mathrm{NO} \rightarrow \mathrm{Cl}+\mathrm{NO}_{2}$ & $\begin{array}{c}k_{\mathrm{g}, 21}=6.2 \times 10^{-12} \times \exp (295 / T) \mathrm{cm}^{3} \\
\mathrm{~s}^{-1}\end{array}$ & Xue et al. ${ }^{3}$ \\
\hline $22 * *$ & $\mathrm{~N}_{2} \mathrm{O}_{5}+$ Aerosol $\rightarrow$ Products & $\begin{array}{c}k_{\mathrm{g}, 22}=0.25 \times \omega_{\mathrm{N} 2 \mathrm{O} 5} \times \gamma_{\mathrm{N} 2 \mathrm{O} 5} \times S_{\mathrm{AERO}} \times \\
\left(1-\varphi_{\mathrm{CINO} 2}\right) \mathrm{s}^{-1} \\
\left(\gamma_{\mathrm{N} 2 \mathrm{O} 5}=1 \times 10^{-2}, \varphi_{\mathrm{CINO} 2}=0.5\right)\end{array}$ & $\begin{array}{l}\text { Xue et al. }{ }^{3} \text {; Wong et } \\
\text { al. }{ }^{22}\end{array}$ \\
\hline $23^{* *}$ & $\begin{array}{c}\mathrm{N}_{2} \mathrm{O}_{5}+\text { Aerosol } \rightarrow \mathrm{ClNO}_{2}+ \\
\text { Products }\end{array}$ & $\begin{array}{c}k_{\mathrm{g}, 23}=0.25 \times \omega_{\mathrm{N} 205} \times \gamma_{\mathrm{N} 205} \times S_{\mathrm{AERO}} \times \\
\varphi_{\mathrm{CINO2}} \mathrm{s}^{-1} \\
\left(\gamma_{\mathrm{N} 2 \mathrm{O} 5}=1 \times 10^{-2}, \varphi_{\mathrm{CINO} 2}=0.5\right)\end{array}$ & $\begin{array}{l}\text { Xue et al. }{ }^{3} \text {; Wong et } \\
\text { al. }{ }^{22}\end{array}$ \\
\hline $24^{* *}$ & $\mathrm{NO}_{3}+$ Aerosol $\rightarrow$ Products & $\begin{array}{c}k_{\mathrm{g}, 24}=0.25 \times \omega_{\mathrm{NO} 3} \times \gamma_{\mathrm{NO} 3} \times S_{\mathrm{AERO}} \mathrm{s}^{-1} \\
\left(\gamma_{\mathrm{NO} 3}=4 \times 10^{-3}\right)\end{array}$ & $\begin{array}{l}\text { Xue et al. }{ }^{3} \text {; Wong et } \\
\text { al. }{ }^{22}\end{array}$ \\
\hline $25^{* *}$ & $\mathrm{ClONO}_{2}+$ Aerosol $\rightarrow \mathrm{Cl}_{2}+\mathrm{HNO}_{3}$ & $\begin{array}{c}k_{\mathrm{g}, 25}=0.25 \times \omega_{\mathrm{ClONO} 2} \times \gamma_{\mathrm{ClONO} 2} \times \\
S_{\mathrm{AERO}} \mathrm{S}^{-1} \\
\left(\gamma_{\mathrm{ClONO} 2}=1 \times 10^{-2}\right)\end{array}$ & $\begin{array}{l}\text { Xue et al. }{ }^{3} \text {; Wong et } \\
\text { al. }{ }^{22}\end{array}$ \\
\hline $26^{* *}$ & $\mathrm{HOCl}+$ Aerosol $\rightarrow \mathrm{Cl}_{2}$ & $\begin{array}{c}k_{\mathrm{g}, 26}=0.25 \times \omega_{\mathrm{HOCl}} \times \gamma_{\mathrm{HOCl}} \times S_{\mathrm{AERO}} \mathrm{S}^{-1} \\
\left(\gamma_{\mathrm{HOCl}}=0.4\right)\end{array}$ & $\begin{array}{l}\text { Xue et al. }{ }^{3} \text {; fitting } \\
\text { parameter }\end{array}$ \\
\hline 27 & $\mathrm{Cl}+(\mathrm{VOCs}) \rightarrow \mathrm{HCl}+(\mathrm{VOCs})$ & $k_{\mathrm{g}, 27}=3 \mathrm{~s}^{-1}$ & assumed to be fast \\
\hline 28 & $\mathrm{OH}+(\mathrm{VOCs}) \rightarrow(\mathrm{VOCs})$ & $k_{\mathrm{g}, 28}=3 \mathrm{~s}^{-1}$ & assumed to be fast \\
\hline 29 & $\mathrm{~N}_{2} \mathrm{O}_{5}+\mathrm{HCl} \rightarrow \mathrm{ClNO}_{2}+\mathrm{HNO}_{3}$ & $k_{\mathrm{g}, 29}=6.7 \times 10^{-21} \mathrm{~cm}^{3} \mathrm{~s}^{-1}$ & $\begin{array}{l}\text { Wilkins Jr and } \\
\text { Hisatsune }^{28}\end{array}$ \\
\hline 30 & $\mathrm{NO}_{2}+\mathrm{hv} \rightarrow \mathrm{NO}+\mathrm{O}$ & $j_{\mathrm{NO} 2}=$ see Table S4 & \\
\hline 31 & $\mathrm{NO}_{3}+\mathrm{hv} \rightarrow \mathrm{NO}_{2}+\mathrm{O}$ & $j_{\mathrm{NO} 3}=$ see Table S4 & \\
\hline 32 & $\mathrm{HONO}+\mathrm{hv} \rightarrow \mathrm{NO}+\mathrm{OH}$ & $j_{\text {HONO }}=$ see Table S4 & \\
\hline 33 & $\mathrm{OH}+\mathrm{O}_{3} \rightarrow \mathrm{HO}_{2}+\mathrm{O}_{2}$ & $k_{\mathrm{g}, 33}=7.3 \times 10^{-14} \mathrm{~cm}^{3} \mathrm{~s}^{-1}$ & Atkinson et al. ${ }^{27}$ \\
\hline 34 & $\mathrm{HO}_{2}+\mathrm{NO} \rightarrow \mathrm{OH}+\mathrm{NO}_{2}$ & $k_{\mathrm{g}, 34}=8.8 \times 10^{-12} \mathrm{~cm}^{3} \mathrm{~s}^{-1}$ & Atkinson et al. ${ }^{27}$ \\
\hline 35 & $\mathrm{HO}_{2}+\mathrm{O}_{3} \rightarrow \mathrm{OH}+2 \mathrm{O}_{2}$ & $k_{\mathrm{g}, 35}=2.0 \times 10^{-15} \mathrm{~cm}^{3} \mathrm{~s}^{-1}$ & Atkinson et al. ${ }^{27}$ \\
\hline $36 * *$ & $\mathrm{NO}_{2}+$ Aerosol $\rightarrow$ Product & $\begin{aligned} k_{\mathrm{g}, 36}= & 0.25 \times \omega_{\mathrm{NO} 2} \times \gamma_{\mathrm{NO} 2} \times S_{\mathrm{AERO}} \mathrm{s}^{-1} \\
& \left(\gamma_{\mathrm{NO} 2}=\text { see Table } \mathrm{S} 4\right)\end{aligned}$ & fitting parameter \\
\hline $37^{* *}$ & $\mathrm{HO}_{2}+$ Aerosol $\rightarrow$ Product & $\begin{array}{c}k_{\mathrm{g}, 37}=0.25 \times \omega_{\mathrm{HO} 2} \times \gamma_{\mathrm{HO} 2} \times S_{\mathrm{AERO}} \mathrm{s}^{-1} \\
\left(\gamma_{\mathrm{HO} 2}=0.5\right)\end{array}$ & George et al. ${ }^{29}$ \\
\hline 38 & $\mathrm{OH}+\mathrm{NO} \rightarrow \mathrm{HONO}$ & $k_{\mathrm{g}, 38}=3.3 \times 10^{-11} \mathrm{~cm}^{3} \mathrm{~s}^{-1}$ & Atkinson et al. ${ }^{27}$ \\
\hline 39 & $\mathrm{OH}+\mathrm{HONO} \rightarrow \mathrm{NO}_{2}+\mathrm{H}_{2} \mathrm{O}$ & $k_{\mathrm{g}, 39}=6.0 \times 10^{-12} \mathrm{~cm}^{3} \mathrm{~s}^{-1}$ & Atkinson et al. ${ }^{27}$ \\
\hline 40 & $\mathrm{HOCl}+\mathrm{NO} \rightarrow \mathrm{NO}_{2}+\mathrm{HCl}$ & $k_{\mathrm{g}, 40}=1.0 \times 10^{-18} \mathrm{~cm}^{3} \mathrm{~s}^{-1}$ & Cook et al. ${ }^{30}$ \\
\hline
\end{tabular}




\begin{tabular}{|c|c|c|c|}
\hline 41 & $\mathrm{O}+\mathrm{O}_{2}+\mathrm{M} \rightarrow \mathrm{O}_{3}+\mathrm{M}$ & $k_{\mathrm{g}, 41}=6.0 \times 10^{-34} \mathrm{~cm}^{6} \mathrm{~s}^{-1}$ & Atkinson et al. ${ }^{27}$ \\
\hline 42 & $\mathrm{O}+\mathrm{NO}_{2}+\mathrm{M} \rightarrow \mathrm{NO}_{3}+\mathrm{M}$ & $k_{\mathrm{g}, 42}=1.3 \times 10^{-31} \mathrm{~cm}^{6} \mathrm{~s}^{-1}$ & Atkinson et al. ${ }^{27}$ \\
\hline 43 & $\mathrm{O}+\mathrm{NO}+\mathrm{M} \rightarrow \mathrm{NO}_{2}+\mathrm{M}$ & $k_{\mathrm{g}, 43}=1.0 \times 10^{-31} \mathrm{~cm}^{6} \mathrm{~s}^{-1}$ & Atkinson et al. ${ }^{27}$ \\
\hline $44^{* * *}$ & $\mathrm{Cl}_{2} \rightarrow$ Products (on surfaces) & $k_{\mathrm{s}, 44}=$ see Table S4 & fitting parameter \\
\hline $45^{* * *}$ & $\mathrm{ClNO}_{2} \rightarrow$ Products (on surfaces) & $k_{\mathrm{s}, 45}=$ see Table S4 & fitting parameter \\
\hline $46 * * *$ & $\mathrm{NCl}_{3} \rightarrow$ Products (on surfaces) & $k_{\mathrm{s}, 46}=$ see Table S4 & fitting parameter \\
\hline $47^{* * *}$ & $\mathrm{Cl}_{2} \mathrm{O} \rightarrow$ Products (on surfaces) & $k_{\mathrm{s}, 47}=2.0 \times 10^{-3} \mathrm{~s}^{-1}$ & fitting parameter \\
\hline $48 * * *$ & $\mathrm{NO}_{2} \rightarrow \mathrm{HONO}$ (on surfaces) & $k_{\mathrm{s}, 48}=1.4 \times 10^{-5} \mathrm{~s}^{-1}$ & fitting parameter \\
\hline $49 * * *$ & $\mathrm{NHCl}_{2} \rightarrow$ Products (on surfaces) & $k_{\mathrm{s}, 49}=1.4 \times 10^{-4} \mathrm{~s}^{-1}$ & fitting parameter \\
\hline $50 * * *$ & $\begin{array}{c}\mathrm{HOCl}+\mathrm{NO} \rightarrow \mathrm{NO}_{2}+\mathrm{HCl} \text { (on } \\
\text { surfaces) }\end{array}$ & $k_{\mathrm{s}, 50}=$ see Table S4 & fitting parameter \\
\hline $51 * * *$ & $\begin{array}{c}\mathrm{HOCl}+\mathrm{HONO} \rightarrow \text { Products (on } \\
\text { surfaces) }\end{array}$ & $k_{\mathrm{s}, 51}=$ see Table $\mathrm{S} 4$ & fitting parameter \\
\hline
\end{tabular}

* The literature value was $7.0 \times 10^{-11} \mathrm{~cm}^{3} \mathrm{~s}^{-1}$ but was decreased slightly to fit the data.

** $\omega_{X}$ is the molecular speed of species $X, \gamma_{X}$ is the uptake coefficient of species $X$, and $S_{\text {AERo }}$ is the aerosol surface area concentration.

*** These reactions are assumed to occur on surfaces but are treated as losses from the gas-phase. They may also include currently unknown gas-phase reactions.

Table S3 - Henry's Law and gas-phase diffusion coefficients used in kinetic model.

\begin{tabular}{|c|c|c|}
\hline Species & $\begin{array}{l}\text { Henry's Law coefficient } \\
\left(\mathrm{mol} \mathrm{cm}^{-3} \mathrm{~atm}^{-1}\right)^{*}\end{array}$ & $\begin{array}{l}\text { Gas-phase diffusion } \\
\text { coefficient }\left(\mathrm{cm}^{2} \mathrm{~s}^{-1}\right)^{* *}\end{array}$ \\
\hline $\mathrm{NH}_{3}$ & 0.06 & 0.23 \\
\hline $\mathrm{NCl}_{3}$ & $9.9 \times 10^{-5}$ & 0.096 \\
\hline $\mathrm{NHCl}_{2}$ & $2.9 \times 10^{-2}$ & 0.11 \\
\hline $\mathrm{HOCl}$ & 0.6 & 0.15 \\
\hline $\mathrm{Cl}_{2}$ & $9.2 \times 10^{-5}$ & 0.13 \\
\hline $\mathrm{NH}_{2} \mathrm{Cl}$ & $8.6 \times 10^{-2}$ & 0.14 \\
\hline $\mathrm{HCl}$ & 0.72 & 0.17 \\
\hline I (intermediate) & Non-volatile & $\mathrm{N} / \mathrm{A}$ \\
\hline $\mathrm{OCl}-$ & Non-volatile & $\mathrm{N} / \mathrm{A}$ \\
\hline $\mathrm{Cl}$ & $2.3 \times 10^{-3}$ & 0.18 \\
\hline $\mathrm{OH}$ & 0.03 & $0.24 * * * *$ \\
\hline $\mathrm{ClNO}_{2}$ & $4 \times 10^{-5}$ & 0.12 \\
\hline
\end{tabular}




\begin{tabular}{ccc}
\hline $\mathrm{NO}_{2}$ & $1.4 \times 10^{-5}$ & 0.17 \\
\hline $\mathrm{ClONO}_{2}$ & $0.011 * * *$ & 0.11 \\
\hline $\mathrm{NO}_{3}$ & $3.4 \times 10^{-5}$ & 0.15 \\
$\mathrm{ClO}$ & $7.0 \times 10^{-4}$ & 0.16 \\
\hline $\mathrm{N}_{2} \mathrm{O}_{5}$ & $2.1 \times 10^{-3}$ & 0.11 \\
\hline $\mathrm{O}_{3}$ & $1 \times 10^{-5}$ & 0.18 \\
\hline $\mathrm{HO}_{2}$ & 5 & 0.20 \\
$\mathrm{H}_{2} \mathrm{O}_{2}$ & 70 & 0.19 \\
\hline $\mathrm{NO}$ & $1.9 \times 10^{-6}$ & 0.20 \\
\hline $\mathrm{HNO}_{3}$ & 210 & 0.14 \\
\hline $\mathrm{Cl}^{-}$ & Non-volatile & $\mathrm{N} / \mathrm{A}$ \\
\hline $\mathrm{Cl}_{2} \mathrm{O}$ & $1.7 \times 10^{-2}$ & 0.12 \\
\hline $\mathrm{HONO}^{\mathrm{O}}$ & 0.048 & 0.16 \\
\hline $\mathrm{O}$ & $1 \times 10^{-5 * * * * *}$ & 0.32 \\
\hline
\end{tabular}

* From Sander ${ }^{31}$ unless otherwise stated.

** From https://www3.epa.gov/ceampubl/learn2model/part-two/onsite/estdiffusion-ext.html unless otherwise stated.

*** From Shi et al. ${ }^{32}$.

$* * * *$ From Tang et al. ${ }^{33}$.

$* * * * *$ Assumed to be the same as $\mathrm{O}_{3}$.

Table S4 - Parameters which varied between different times and days in kinetic model.

\begin{tabular}{|c|c|c|c|c|c|c|c|}
\hline Parameter & $\begin{array}{c}10 \text { June } \\
08: 35\end{array}$ & $\begin{array}{c}10 \text { June } \\
12: 35\end{array}$ & $\begin{array}{c}10 \text { June } \\
16: 35\end{array}$ & $\begin{array}{l}10 \text { June } \\
20: 35\end{array}$ & $\begin{array}{l}8 \text { June } \\
17: 35\end{array}$ & $\begin{array}{c}19 \text { June } \\
17: 35\end{array}$ & $\begin{array}{c}25 \text { June } \\
17: 35\end{array}$ \\
\hline $\operatorname{AER}\left(\mathrm{h}^{-1}\right)^{*}$ & 0.66 & 0.60 & 0.64 & 0.78 & 0.70 & 0.43 & 0.59 \\
\hline $\mathrm{K}_{\mathrm{e}}\left(\mathrm{s}^{-1}\right)$ & 10 & 3 & 10 & 5 & 3 & 3 & 1 \\
\hline $\begin{array}{c}k_{\mathrm{aq}, 3}\left(\mathrm{~cm}^{3} \mathrm{~s}^{-}\right. \\
1)\end{array}$ & $2.9 \times 10^{-18}$ & $2.0 \times 10^{-18}$ & $1.3 \times 10^{-18}$ & $7.2 \times 10^{-19}$ & $5.0 \times 10^{-18}$ & $1.0 \times 10^{-17}$ & $5.0 \times 10^{-18}$ \\
\hline $\begin{array}{c}k_{\mathrm{aq}, 14}\left(\mathrm{~cm}^{3} \mathrm{~s}^{-}\right. \\
1)\end{array}$ & $1.3 \times 10^{-19}$ & $6.3 \times 10^{-20}$ & $5.4 \times 10^{-20}$ & $5.4 \times 10^{-20}$ & $7.6 \times 10^{-20}$ & $2.5 \times 10^{-19}$ & $3.2 \times 10^{-20}$ \\
\hline $\begin{array}{c}k_{\mathrm{aq}, 23}\left(\mathrm{~cm}^{3} \mathrm{~s}^{-}\right. \\
1)\end{array}$ & $1.5 \times 10^{-4}$ & $1.3 \times 10^{-4}$ & $8.7 \times 10^{-5}$ & $7.4 \times 10^{-5}$ & $2.6 \times 10^{-4}$ & $3.2 \times 10^{-4}$ & $2.4 \times 10^{-4}$ \\
\hline $\begin{array}{c}k_{\mathrm{aq}, 24}\left(\mathrm{~cm}^{3} \mathrm{~s}^{-}\right. \\
1)\end{array}$ & 2.5 & 2.5 & 2.5 & 2 & 2 & 2 & 2.5 \\
\hline$j_{\mathrm{C} 12}\left(\mathrm{~s}^{-1}\right)^{* *}$ & $\begin{array}{c}2.2 \times 10^{-4} \\
/ 50\end{array}$ & $\begin{array}{c}1.2 \times 10^{-} \\
4 / 50\end{array}$ & $\begin{array}{c}3.4 \times 10^{-4} \\
/ 50\end{array}$ & 0 & $\begin{array}{c}2.6 \times 10^{-4} \\
/ 50\end{array}$ & $\begin{array}{c}2.6 \times 10^{-4} \\
/ 50\end{array}$ & $\begin{array}{c}2.6 \times 10^{-4} \\
/ 50\end{array}$ \\
\hline$j_{\text {HOCI }}\left(s^{-1}\right)^{* *}$ & $\begin{array}{c}2.1 \times 10^{-5} \\
/ 50\end{array}$ & $\begin{array}{c}1.1 \times 10^{-5} \\
/ 50\end{array}$ & $\begin{array}{c}3.1 \times 10^{-5} \\
/ 50\end{array}$ & 0 & $\begin{array}{c}2.4 \times 10^{-5} \\
/ 50\end{array}$ & $\begin{array}{c}2.4 \times 10^{-5} \\
/ 50\end{array}$ & $\begin{array}{c}2.4 \times 10^{-5} \\
/ 50\end{array}$ \\
\hline
\end{tabular}




\begin{tabular}{|c|c|c|c|c|c|c|c|}
\hline$j_{\mathrm{CINO} 2}\left(\mathrm{~s}^{-1}\right)^{* *}$ & $\begin{array}{c}1.6 \times 10^{-5} \\
/ 50\end{array}$ & $\begin{array}{c}8.2 \times 10^{-6} \\
/ 50\end{array}$ & $\begin{array}{c}2.3 \times 10^{-5} \\
/ 50\end{array}$ & 0 & $\begin{array}{c}1.7 \times 10^{-5} \\
/ 50\end{array}$ & $\begin{array}{c}1.7 \times 10^{-5} \\
/ 50\end{array}$ & $\begin{array}{c}1.7 \times 10^{-5} \\
/ 50\end{array}$ \\
\hline$j_{\mathrm{NO} 2}\left(\mathrm{~s}^{-1}\right)^{* *}$ & $\begin{array}{c}1.4 \times 10^{-3} \\
/ 50\end{array}$ & $\begin{array}{c}7.5 \times 10^{-4} \\
/ 50\end{array}$ & $\begin{array}{c}2.2 \times 10^{-3} \\
/ 50\end{array}$ & 0 & $\begin{array}{c}1.7 \times 10^{-3} \\
/ 50\end{array}$ & $\begin{array}{c}1.7 \times 10^{-3} \\
/ 50\end{array}$ & $\begin{array}{c}1.7 \times 10^{-3} \\
/ 50\end{array}$ \\
\hline$j_{\mathrm{NO}}\left(\mathrm{s}^{-1}\right)^{* *}$ & $\begin{array}{c}7.5 \times 10^{-2} \\
/ 50\end{array}$ & $\begin{array}{c}2.3 \times 10^{-2} \\
/ 50\end{array}$ & $0.13 / 50$ & 0 & $0.11 / 50$ & $0.11 / 50$ & $0.11 / 50$ \\
\hline$j_{\text {HONO }}\left(\mathrm{s}^{-1}\right)^{* *}$ & $\begin{array}{c}1.8 \times 10^{-4} \\
/ 50\end{array}$ & $\begin{array}{c}1.0 \times 10^{-4} \\
/ 50\end{array}$ & $\begin{array}{c}2.8 \times 10^{-4} \\
/ 50\end{array}$ & 0 & $\begin{array}{c}2.1 \times 10^{-4} \\
/ 50\end{array}$ & $\begin{array}{c}2.1 \times 10^{-4} \\
/ 50\end{array}$ & $\begin{array}{c}2.1 \times 10^{-4} \\
/ 50\end{array}$ \\
\hline$\gamma_{\mathrm{NO} 2}$ & 0.08 & 0.08 & 0.08 & 0.08 & 0.08 & 0.04 & 0.06 \\
\hline$k_{\mathrm{s}, 44}\left(\mathrm{~s}^{-1}\right)$ & $2.0 \times 10^{-3}$ & $2.0 \times 10^{-3}$ & $2.0 \times 10^{-3}$ & $3.0 \times 10^{-3}$ & $4.0 \times 10^{-3}$ & $2.0 \times 10^{-3}$ & $1.0 \times 10^{-3}$ \\
\hline$k_{\mathrm{s}, 45}\left(\mathrm{~s}^{-1}\right)$ & $5.5 \times 10^{-4}$ & $4.4 \times 10^{-4}$ & $3.3 \times 10^{-4}$ & $2.5 \times 10^{-4}$ & $1.1 \times 10^{-3}$ & $2.2 \times 10^{-4}$ & $3.0 \times 10^{-4}$ \\
\hline$k_{\mathrm{s}, 46}\left(\mathrm{~s}^{-1}\right)$ & $8.3 \times 10^{-4}$ & $8.3 \times 10^{-4}$ & $8.3 \times 10^{-4}$ & $4.2 \times 10^{-4}$ & $8.3 \times 10^{-4}$ & $4.2 \times 10^{-4}$ & $4.2 \times 10^{-4}$ \\
\hline$k_{\mathrm{s}, 50}\left(\mathrm{~cm}^{3} \mathrm{~s}^{-1}\right)$ & $1.0 \times 10^{-16}$ & $1.0 \times 10^{-16}$ & $1.0 \times 10^{-16}$ & $1.0 \times 10^{-16}$ & $1.0 \times 10^{-16}$ & $1.0 \times 10^{-16}$ & $1.0 \times 10^{-15}$ \\
\hline$k_{\mathrm{s}, 51}\left(\mathrm{~cm}^{3} \mathrm{~s}^{-1}\right)$ & $1.0 \times 10^{-15}$ & $1.0 \times 10^{-15}$ & $1.0 \times 10^{-15}$ & $1.0 \times 10^{-15}$ & $1.0 \times 10^{-15}$ & $5.0 \times 10^{-16}$ & $1.0 \times 10^{-15}$ \\
\hline $\begin{array}{c}\mathrm{P}_{\mathrm{NH} 3}\left(\mathrm{~cm}^{-3} \mathrm{~s}^{-}\right. \\
1) * * *\end{array}$ & $\begin{array}{c}7.9 \times 10^{11} \\
\times A E R\end{array}$ & $\begin{array}{c}6.4 \times 10^{11} \\
\times A E R\end{array}$ & $\begin{array}{c}6.4 \times 10^{11} \\
\times A E R\end{array}$ & $\begin{array}{l}1.7 \times 10^{11} \\
\times A E R\end{array}$ & $\begin{array}{c}6.4 \times 10^{11} \\
\times A E R\end{array}$ & $\begin{array}{c}9.8 \times 10^{11} \\
\times A E R\end{array}$ & $\begin{array}{l}4.9 \times 10^{11} \\
\times A E R\end{array}$ \\
\hline $\begin{array}{c}\mathrm{P}_{\mathrm{NO} 2}\left(\mathrm{~cm}^{-3} \mathrm{~s}^{-}\right. \\
1) * * *\end{array}$ & $\begin{array}{c}4.3 \times 10^{10} \\
\times A E R\end{array}$ & $\begin{array}{c}4.3 \times 10^{10} \\
\times A E R\end{array}$ & $\begin{array}{c}5.9 \times 10^{10} \\
\times A E R\end{array}$ & $\begin{array}{l}8.3 \times 10^{10} \\
\times A E R\end{array}$ & $\begin{array}{c}1.2 \times 10^{11} \\
\times A E R\end{array}$ & $\begin{array}{l}2.2 \times 10^{11} \\
\times A E R\end{array}$ & $\begin{array}{l}1.4 \times 10^{11} \\
\times A E R\end{array}$ \\
\hline $\begin{array}{c}\mathrm{P}_{\mathrm{NO}}\left(\mathrm{cm}^{-3} \mathrm{~s}^{-}\right. \\
1) * * *\end{array}$ & $\begin{array}{c}4.2 \times 10^{10} \\
\times A E R\end{array}$ & $\begin{array}{c}4.2 \times 10^{10} \\
\times A E R\end{array}$ & $\begin{array}{c}3.9 \times 10^{10} \\
\times A E R\end{array}$ & $\begin{array}{c}1.5 \times 10^{10} \\
\times A E R\end{array}$ & $\begin{array}{c}3.5 \times 10^{10} \\
\times A E R\end{array}$ & $\begin{array}{c}5.6 \times 10^{10} \\
\times A E R\end{array}$ & $\begin{array}{c}5.0 \times 10^{10} \\
\times A E R\end{array}$ \\
\hline $\begin{array}{c}\mathrm{P}_{\mathrm{O} 3}\left(\mathrm{~cm}^{-3} \mathrm{~s}^{-1}\right) \\
* * *\end{array}$ & $\begin{array}{c}1.7 \times 10^{11} \\
\times A E R\end{array}$ & $\begin{array}{c}1.7 \times 10^{11} \\
\times A E R\end{array}$ & $\begin{array}{c}1.7 \times 10^{11} \\
\times A E R\end{array}$ & $\begin{array}{c}1.7 \times 10^{11} \\
\times A E R\end{array}$ & $\begin{array}{c}1.7 \times 10^{11} \\
\times A E R\end{array}$ & $\begin{array}{c}1.7 \times 10^{11} \\
\times A E R\end{array}$ & $\begin{array}{c}1.7 \times 10^{11} \\
\times A E R\end{array}$ \\
\hline $\begin{array}{c}\mathrm{P}_{\mathrm{HONO}}\left(\mathrm{cm}^{-3}\right. \\
\left.\mathrm{s}^{-1}\right) * * *\end{array}$ & $\begin{array}{c}6.2 \times 10^{9} \times \\
A E R\end{array}$ & $\begin{array}{c}6.2 \times 10^{9} \times \\
A E R\end{array}$ & $\begin{array}{c}6.2 \times 10^{9} \times \\
A E R\end{array}$ & $\begin{array}{c}6.2 \times 10^{9} \times \\
A E R\end{array}$ & $\begin{array}{c}6.2 \times 10^{9} \times \\
A E R\end{array}$ & $\begin{array}{c}1.4 \times 10^{10} \\
\times A E R\end{array}$ & $\begin{array}{c}6.2 \times 10^{9} \times \\
A E R\end{array}$ \\
\hline $\begin{array}{c}\mathrm{P}_{\mathrm{NO} \_ \text {indoors }} \\
\left(\mathrm{cm}^{-3} \mathrm{~s}^{-1}\right) \\
* * *\end{array}$ & $1.4 \times 10^{7}$ & $1.4 \times 10^{7}$ & $7.1 \times 10^{6}$ & $1.4 \times 10^{7}$ & $7.1 \times 10^{6}$ & $2.1 \times 10^{7}$ & $7.1 \times 10^{6}$ \\
\hline $\begin{array}{c}\mathrm{P}_{\mathrm{NO} 2 \text { indoors }} \\
\left(\mathrm{cm}^{-3} \mathrm{~s}^{-1}\right) \\
* * *\end{array}$ & $2.1 \times 10^{7}$ & $2.1 \times 10^{7}$ & $3.6 \times 10^{7}$ & $5.0 \times 10^{7}$ & $5.0 \times 10^{7}$ & $2.1 \times 10^{7}$ & $7.1 \times 10^{6}$ \\
\hline
\end{tabular}

\footnotetext{
* All species were removed from the gas-phase at the AER.

** Upper-bound photolysis rates from measurements were divided by a factor of 50 .

*** $\mathrm{P}_{\mathrm{X}}$ represents a production rate of molecules due to outdoor-to-indoor transport, while $\mathrm{P}_{\mathrm{X} \text { _indoors }}$ represents an indoor production. $\mathrm{P}_{\mathrm{NH} 3}, \mathrm{P}_{\mathrm{O} 3}, \mathrm{P}_{\mathrm{NO} \_ \text {indoors }}$ and $\mathrm{P}_{\mathrm{NO} 2 \text { _indoors }}$ were fitting parameters while $\mathrm{P}_{\mathrm{NO} 2}, \mathrm{P}_{\mathrm{NO}}$ and $\mathrm{P}_{\text {HONO }}$ were based on measurements of these species outdoors. Note that $P_{03}$ was changed for the window opening scenarios. AER was in units of $\mathrm{s}^{-1}$.
} 
Table S5 - Outdoor mixing ratios and I- TOF-CIMS instrumental detection limits for various bleachrelated compounds during HOMEChem.

\begin{tabular}{cccccc}
\hline \multicolumn{5}{c}{ Outdoor mixing ratio (pptv) } & Detection limit \\
(pptv)
\end{tabular}

Outdoor measurements taken during bleach cleaning experiments on 8, 10, 19, and 25 June 2018. pptv = part-pertrillion by volume. $\mathrm{BDL}=$ below detection limit; S. D. = standard deviation. $\left({ }^{*}\right)$ denotes mixing ratios are estimates. (--) denotes missing data.

Table S6 - Kinetic model predictions of total $\mathrm{OH}$ radical production (\%) from individual reaction mechanisms during bleach cleaning experiments at HOMEChem.

\begin{tabular}{cccccccc}
\hline Reaction & $\begin{array}{c}\text { 10 June } \\
\mathbf{0 8 : 3 5}\end{array}$ & $\begin{array}{c}10 \text { June } \\
\mathbf{1 2 : 3 5}\end{array}$ & $\begin{array}{c}\text { 10 June } \\
\mathbf{1 6}\end{array}$ & $\begin{array}{c}\text { 10 June } \\
\mathbf{2 0 : 3 5}\end{array}$ & $\begin{array}{c}\mathbf{8} \text { June } \\
\mathbf{1 7}: 35\end{array}$ & $\begin{array}{c}\text { 19 June } \\
\mathbf{1 7 : 3 5}\end{array}$ & $\begin{array}{c}\text { 25 June } \\
\mathbf{1 7 : 3 5}\end{array}$ \\
\hline $\mathrm{HOCl}+h v \rightarrow \mathrm{OH}+\mathrm{Cl}$ & 96.0 & 93.5 & 96.4 & -- & 84.9 & 38.0 & 56.0 \\
\hline $\mathrm{Cl}+\mathrm{HO}_{2} \rightarrow \mathrm{ClO}+\mathrm{OH}$ & 0.0 & 0.0 & 0.0 & -- & 0.0 & 0.0 & 0.0 \\
\hline $\mathrm{HONO}+\mathrm{hv} \rightarrow \mathrm{NO}+\mathrm{OH}$ & 3.9 & 6.4 & 3.4 & -- & 15.1 & 62.0 & 43.9 \\
\hline $\mathrm{HO}_{2}+\mathrm{NO} \rightarrow \mathrm{OH}+\mathrm{NO}_{2}$ & 0.2 & 0.2 & 0.2 & -- & 0.0 & 0.0 & 0.2 \\
$\mathrm{HO}_{2}+\mathrm{O}_{3} \rightarrow \mathrm{OH}+2 \mathrm{O}_{2}$ & 0.0 & 0.0 & 0.0 & -- & 0.0 & 0.0 & 0.0 \\
\hline
\end{tabular}

No $\mathrm{OH}$ radical production occurred at 20:35 on 10 June 2018 due to the absence of indoor photolysis reactions. (--) denotes missing data. Radical production was calculated between 0 and 2.5 hours after bleach cleaning.

Table S7 - Kinetic model predictions of total $\mathrm{Cl}$ radical production (\%) from individual reaction mechanisms during bleach cleaning experiments at HOMEChem.

\begin{tabular}{cccccccc}
\hline Reaction & $\begin{array}{c}\text { 10 June } \\
\mathbf{0 8 : 3 5}\end{array}$ & $\begin{array}{c}\text { 10 June } \\
\mathbf{1 2 : 3 5}\end{array}$ & $\begin{array}{c}\text { 10 June } \\
\mathbf{1 6}: 35\end{array}$ & $\begin{array}{c}\text { 10 June } \\
\mathbf{2 0 : 3 5}\end{array}$ & $\begin{array}{c}\text { 8 June } \\
\mathbf{1 7 : 3 5}\end{array}$ & $\begin{array}{c}\text { 19 June } \\
\mathbf{1 7 : 3 5}\end{array}$ & $\begin{array}{c}\text { 25 June } \\
\mathbf{1 7 : 3 5}\end{array}$ \\
\hline $\mathrm{Cl}_{2}+h v \rightarrow 2 \mathrm{Cl}$ & 81.0 & 79.5 & 83.6 & -- & 68.6 & 65.6 & 70.9 \\
$\mathrm{HOCl}+h v \rightarrow \mathrm{OH}+\mathrm{Cl}$ & 8.3 & 8.2 & 8.4 & -- & 6.8 & 3.9 & 2.5 \\
\hline $\mathrm{ClNO}_{2}+h v \rightarrow \mathrm{NO}_{2}+\mathrm{Cl}$ & 0.5 & 0.6 & 0.4 & -- & 0.9 & 2.0 & 1.0
\end{tabular}




\begin{tabular}{cccccccc}
\hline $\mathrm{ClONO}_{2}+h v \rightarrow \mathrm{NO}_{3}+\mathrm{Cl}$ & 0.0 & 0.0 & 0.1 & -- & 0.0 & 0.0 & 0.0 \\
\hline $\mathrm{OH}+\mathrm{HCl} \rightarrow \mathrm{Cl}+\mathrm{H}_{2} \mathrm{O}$ & 0.0 & 0.0 & 0.0 & -- & 0.0 & 0.0 & 0.1 \\
\hline $\mathrm{OH}+\mathrm{Cl} \rightarrow \mathrm{HOCl}+\mathrm{Cl}$ & 0.1 & 0.1 & 0.1 & -- & 0.0 & 0.0 & 0.0 \\
$\mathrm{OH}+\mathrm{ClO} \rightarrow \mathrm{HO}_{2}+\mathrm{Cl}$ & 0.0 & 0.0 & 0.0 & -- & 0.0 & 0.0 & 0.0 \\
\hline $\mathrm{ClO}+\mathrm{NO} \rightarrow \mathrm{Cl}+\mathrm{NO}_{2}$ & 10.0 & 11.6 & 7.3 & -- & 23.7 & 28.4 & 25.4 \\
\hline
\end{tabular}

No $\mathrm{Cl}$ radical production occurred at 20:35 on 10 June 2018 due to the absence of indoor photolysis reactions. (--) denotes missing data. Radical production was calculated between 0 and 2.5 hours after bleach cleaning. 


\section{References}

(1) Farmer, D. K.; Vance, M. E.; Abbatt, J. P. D.; Abeleira, A.; Alves, M. R.; Arata, C.; Boedicker, E.; Bourne, S.; Cardoso-Saldaña, F.; Corsi, R.; DeCarlo, P. F.; Goldstein, A. H.; Grassian, V. H.; Hildebrandt Ruiz, L.; Jimenez, J. L.; Kahan, T. F.; Katz, E. F.; Mattila, J. M.; Nazaroff, W. W.; Novoselac, A.; O'Brien, R. E.; Or, V. W.; Patel, S.; Sankhyan, S.; Stevens, P. S.; Tian, Y.; Wade, M.; Wang, C.; Zhou, S.; Zhou, Y. Overview of HOMEChem: House Observations of Microbial and Environmental Chemistry. Environ. Sci. Process. Impacts 2019, 10.1039/C9EM00228F.

(2) Zahniser, M.; Kaufman, F. Kinetics of the reactions of $\mathrm{ClO}$ with $\mathrm{O}$ and with NO. J. Chem. Phys. 1977, 66 (8), 3673-3681.

(3) Xue, L.; Saunders, S.; Wang, T.; Gao, R.; Wang, X.; Zhang, Q.; Wang, W. Development of a chlorine chemistry module for the Master Chemical Mechanism. Geosci. Model Dev. 2015, 8 (10), 3151-3162.

(4) Liu, Y.; Misztal, P.; Xiong, J.; Tian, Y.; Arata, C.; Nazaroff, W.; Goldstein, A. Detailed investigation of ventilation rates and airflow patterns in a northern California residence. Indoor Air 2018, 28 (4), 572584.

(5) Zhao, J.; Zhang, R. Proton transfer reaction rate constants between hydronium ion $\left(\mathrm{H}_{3} \mathrm{O}^{+}\right)$and volatile organic compounds. Atmos. Environ. 2004, 38 (14), 2177-2185.

(6) Kowal, S. F.; Allen, S. R.; Kahan, T. F. Wavelength-Resolved Photon Fluxes of Indoor Light Sources: Implications for HOx Production. Environ. Sci. Technol. 2017, 51 (18), 10423-10430.

(7) Aljawhary, D.; Lee, A.; Abbatt, J. High-resolution chemical ionization mass spectrometry (ToF-CIMS): application to study SOA composition and processing. Atmos. Meas. Tech. 2013, 6 (11), 3211-3224.

(8) Lopez-Hilfiker, F. D.; Iyer, S.; Mohr, C.; Lee, B. H.; D'Ambro, E. L.; Kurten, T.; Thornton, J. A. Constraining the sensitivity of iodide adduct chemical ionization mass spectrometry to multifunctional organic molecules using the collision limit and thermodynamic stability of iodide ion adducts. Atmos. Meas. Tech. 2016, 9 (4), 1505-1512.

(9) Bertram, T. H.; Kimmel, J. R.; Crisp, T. A.; Ryder, O. S.; Yatavelli, R. L. N.; Thornton, J. A.; Cubison, M. J.; Gonin, M.; Worsnop, D. R. A field-deployable, chemical ionization time-of-flight mass spectrometer. Atmos. Meas. Tech. 2011, 4 (7), 1471-1479.

(10) Foster, K.; Caldwell, T.; Hemminger, J.; Finlayson-Pitts, B. Techniques for quantifying gaseous $\mathrm{HOCl}$ using atmospheric pressure ionization mass spectrometry. Phys. Chem. Chem. Phys. 1999, 1 (24), 56155621.

(11) Lawler, M.; Sander, R.; Carpenter, L.; Lee, J.; Glasow, R. v.; Sommariva, R.; Saltzman, E. $\mathrm{HOCl}$ and $\mathrm{Cl}_{2}$ observations in marine air. Atmos. Chem. Phys. 2011, 11 (15), 7617-7628.

(12) Dubé, W. P.; Brown, S. S.; Osthoff, H. D.; Nunley, M. R.; Ciciora, S. J.; Paris, M. W.; McLaughlin, R. J.; Ravishankara, A. Aircraft instrument for simultaneous, in situ measurement of $\mathrm{NO}_{3}$ and $\mathrm{N}_{2} \mathrm{O}_{5}$ via pulsed cavity ring-down spectroscopy. Rev. Sci. Instrum. 2006, 77 (3), 034101.

(13) Fuchs, H.; Dubé, W. P.; Ciciora, S. J.; Brown, S. S. Determination of inlet transmission and conversion efficiencies for in situ measurements of the nocturnal nitrogen oxides, $\mathrm{NO}_{3}, \mathrm{~N}_{2} \mathrm{O}_{5}$ and $\mathrm{NO}_{2}$, via pulsed cavity ring-down spectroscopy. Anal. Chem. 2008, 80 (15), 6010-6017.

(14) Wagner, N.; Dubé, W.; Washenfelder, R.; Young, C.; Pollack, I.; Ryerson, T.; Brown, S. Diode laserbased cavity ring-down instrument for $\mathrm{NO}_{3}, \mathrm{~N}_{2} \mathrm{O}_{5}, \mathrm{NO}, \mathrm{NO}_{2}$ and $\mathrm{O}_{3}$ from aircraft. Atmos. Meas. Tech. 2011, 4 (6), 1227-1240.

(15) Leu, M.-T.; Timonen, R. S.; Keyser, L. F.; Yung, Y. L. Heterogeneous reactions of $\mathrm{HNO}_{3}(\mathrm{~g})+\mathrm{NaCl}(\mathrm{s}) \rightarrow$ $\mathrm{HCl}(\mathrm{g})+\mathrm{NaNO}_{3}(\mathrm{~s})$ and $\mathrm{N}_{2} \mathrm{O}_{5}(\mathrm{~g})+\mathrm{NaCl}(\mathrm{s}) \rightarrow \mathrm{ClNO}_{2}(\mathrm{~g})+\mathrm{NaNO}_{3}(\mathrm{~s})$. J. Phys. Chem. 1995, 99 (35), 1320313212.

(16) Finlayson-Pitts, B. The tropospheric chemistry of sea salt: A molecular-level view of the chemistry of $\mathrm{NaCl}$ and $\mathrm{NaBr}$. Chem. Rev. 2003, 103 (12), 4801-4822. 
(17) Lee, B. H.; Lopez-Hilfiker, F. D.; Mohr, C.; Kurten, T.; Worsnop, D. R.; Thornton, J. A. An iodideadduct high-resolution time-of-flight chemical-ionization mass spectrometer: application to atmospheric inorganic and organic compounds. Environ. Sci. Technol. 2014, 48 (11), 6309-17.

(18) Kercher, J.; Riedel, T.; Thornton, J. Chlorine activation by $\mathrm{N}_{2} \mathrm{O}_{5}$ : simultaneous, in situ detection of $\mathrm{CINO}_{2}$ and $\mathrm{N}_{2} \mathrm{O}_{5}$ by chemical ionization mass spectrometry. Atmos. Meas. Tech. 2009, 2 (1), 193-204.

(19) Brophy, P.; Farmer, D. K. Clustering, methodology, and mechanistic insights into acetate chemical ionization using high-resolution time-of-flight mass spectrometry. Atmos. Meas. Tech. 2016, 9 (8), 39693986.

(20) Iyer, S.; Lopez-Hilfiker, F.; Lee, B. H.; Thornton, J. A.; Kurtén, T. Modeling the detection of organic and inorganic compounds using iodide-based chemical ionization. J. Phys. Chem. A 2016, 120 (4), 576587.

(21) Huey, L. G.; Hanson, D. R.; Howard, C. J. Reactions of $\mathrm{SF}_{6}{ }^{-}$and I- with atmospheric trace gases. J. Phys. Chem. 1995, 99 (14), 5001-5008.

(22) Wong, J.; Carslaw, N.; Zhao, R.; Zhou, S.; Abbatt, J. Observations and impacts of bleach washing on indoor chlorine chemistry. Indoor Air 2017, 27 (6), 1082-1090.

(23) Jafvert, C. T.; Valentine, R. L. Reaction scheme for the chlorination of ammoniacal water. Environ.

Sci. Technol. 1992, 26 (3), 577-586.

(24) Deborde, M.; Von Gunten, U. Reactions of chlorine with inorganic and organic compounds during water treatment-kinetics and mechanisms: a critical review. Water Res. 2008, 42 (1-2), 13-51.

(25) Eiserich, J. P.; Cross, C. E.; Jones, A. D.; Halliwell, B.; Van der Vliet, A. Formation of nitrating and chlorinating species by reaction of nitrite with hypochlorous acid a novel mechanism for nitric oxidemediated protein modification. J. Biol. Chem. 1996, 271 (32), 19199-19208.

(26) Frenzel, A.; Scheer, V.; Sikorski, R.; George, C.; Behnke, W.; Zetzsch, C. Heterogeneous interconversion reactions of $\mathrm{BrNO}_{2}, \mathrm{ClNO}_{2}, \mathrm{Br}_{2}$, and $\mathrm{Cl}_{2}$. J. Phys. Chem. A 1998, 102 (8), 1329-1337.

(27) Atkinson, R.; Baulch, D. L.; Cox, R. A.; Crowley, J. N.; Hampson, R. F.; Hynes, R. G.; Jenkin, M. E.; Rossi, M. J.; Troe, J. Evaluated kinetic and photochemical data for atmospheric chemistry: Volume I - gas phase reactions of $\mathrm{O}_{x}, \mathrm{HO}_{x}, \mathrm{NO}_{x}$ and $\mathrm{SO}_{x}$ species. Atmos. Chem. Phys. 2004, 4 (6), 1461-1738.

(28) Wilkins Jr, R. A.; Hisatsune, I. The reaction of dinitrogen pentoxide with hydrogen chloride. Ind. Eng. Chem. Fundam. 1976, 15 (4), 246-248.

(29) George, I.; Matthews, P.; Whalley, L.; Brooks, B.; Goddard, A.; Baeza-Romero, M.; Heard, D. Measurements of uptake coefficients for heterogeneous loss of $\mathrm{HO}_{2}$ onto submicron inorganic salt aerosols. Phys. Chem. Chem. Phys. 2013, 15 (31), 12829-12845.

(30) Cook, J. E. L.; Ennis, C. A.; Leck, T. J.; Birks, J. W. Studies of reactions of importance in the stratosphere. IV. Rate constant for the reaction $\mathrm{Cl}+\mathrm{HOCl} \rightarrow \mathrm{HCl}+\mathrm{ClO}$ over the temperature range 243-365 K. J. Chem. Phys. 1981, 74 (1), 545-549.

(31) Sander, R. Compilation of Henry's law constants (version 4.0) for water as solvent. Atmos. Chem. Phys. 2015, 15 (8), 4399-4981.

(32) Shi, Q.; Jayne, J.; Kolb, C.; Worsnop, D.; Davidovits, P. Kinetic model for reaction of $\mathrm{ClONO}_{2}$ with $\mathrm{H}_{2} \mathrm{O}$ and $\mathrm{HCl}$ and $\mathrm{HOCl}$ with $\mathrm{HCl}$ in sulfuric acid solutions. J. Geophys. Res. Atmos. 2001, 106 (D20), 2425924274.

(33) Tang, M.; Cox, R.; Kalberer, M. Compilation and evaluation of gas phase diffusion coefficients of reactive trace gases in the atmosphere: volume 1. Inorganic compounds. Atmos. Chem. Phys. 2014, 14

(17), 9233-9247.(1) Abdullahi, K. L.; Delgado-Saborit, J. M.; Harrison, R. M. Emissions and indoor concentrations of particulate matter and its specific chemical components from cooking: A review. Atmos. Environ. 2013, 71, 260-294.

(34) Abdullahi, K. L.; Delgado-Saborit, J. M.; Harrison, R. M. Emissions and indoor concentrations of particulate matter and its specific chemical components from cooking: A review. Atmos. Environ. 2013, $71,260-294$. 
(35) Xu, W.; Lambe, A.; Silva, P.; Hu, W.; Onasch, T.; Williams, L.; Croteau, P.; Zhang, X.; Renbaum-Wolff, L.; Fortner, E. Laboratory evaluation of species-dependent relative ionization efficiencies in the Aerodyne Aerosol Mass Spectrometer. Aerosol Sci. Technol. 2018, 52 (6), 626-641. 